\title{
Wood Vinegar as a Complex Growth Regulator Promotes the Growth, Yield, and Quality of Rapeseed
}

\author{
Kunmiao Zhu, Sicheng Gu, Jiahuan Liu, Tao Luo, Zaid Khan, Kangkang Zhang and Liyong Hu *
}

check for updates

Citation: Zhu, K.; Gu, S.; Liu, J.; Luo, T.; Khan, Z.; Zhang, K.; Hu, L. Wood Vinegar as a Complex Growth Regulator Promotes the Growth, Yield, and Quality of Rapeseed. Agronomy 2021, 11, 510. https:// doi.org/10.3390/agronomy11030510

Academic Editor: Ralf Pude

Received: 17 January 2021

Accepted: 2 March 2021

Published: 9 March 2021

Publisher's Note: MDPI stays neutral with regard to jurisdictional claims in published maps and institutional affiliations.

Copyright: (c) 2021 by the authors. Licensee MDPI, Basel, Switzerland. This article is an open access article distributed under the terms and conditions of the Creative Commons Attribution (CC BY) license (https:/ / creativecommons.org/licenses/by/ $4.0 /)$.
MOA Key Laboratory of Crop Ecophysiology and Farming System in the Middle Reaches of the Yangtze River, College of Plant Science and Technology, Huazhong Agricultural University, Wuhan 430070, China; kunmiaozhu@webmail.hzau.edu.cn (K.Z.); g1535077998@163.com (S.G.); jiahuanliu@webmail.hzau.edu.cn (J.L.); Luotao28@webmail.hzau.edu.cn (T.L.); zaidkhan@webmail.hzau.edu.cn (Z.K.); zhangkk@webmail.hzau.edu.cn (K.Z.)

* Correspondence: liyonghu@mail.hzau.edu.cn

Abstract: Wood vinegar is formed by the condensation of smoke produced during the production of biochar. It mainly contains acetic acid, butyric acid, catechol, and phenol. Wood vinegar has a compound effect of promoting crop growth similar to plant growth regulators and is environmentally friendly. Moreover, it can enhance the biological and abiotic resistance of crops. In this study, foliar spraying was carried out systematically in the field with the hybrid variety of Huayouza 9 for two years to study the effects of wood vinegar and its compounds on the growth of rapeseed (Brassica napus L.). We applied four treatments with tap water as a control (CK), namely wood vinegar diluted 400-fold (M), M mixed with gibberellin (T1), M mixed with sodium D-gluconate (T2), and M mixed with melatonin (T3). They were sprayed in the seedling stage and overwintering stage, respectively. The results showed that the seed yield, the leaf area index, and the number of pods per plant of rapeseed treated with $\mathrm{M}$ increased by an average of $9.58 \%, 23.45 \%$, and $23.80 \%$ in two years as compared to the $\mathrm{CK}$, respectively. Compared with $\mathrm{M}$, the seed yield of rapeseed treated with $\mathrm{T} 1, \mathrm{~T} 2$, and $\mathrm{T} 3$ increased by an average of $7.88 \%, 6.90 \%$, and $1.32 \%$ in two years, respectively. The treatments also improved the quality of rapeseed. In particular, the glucosinolate content of rapeseed treated with $\mathrm{T} 2$ and $\mathrm{T} 3$ decreased by an average of $12.83 \%$ and $6.72 \%$ in two years compared to the $\mathrm{CK}$, respectively. The four treatments selected in the current study improved the resistance of rapeseed at the low temperature of $2-6^{\circ} \mathrm{C}$ by increasing the activity of superoxide dismutase and proline and soluble protein contents, as compared to the CK. Besides, all treatments containing $\mathrm{M}$ reduced the incidence of Sclerotinia sclerotiorum and Peronospora parasitica (downy mildew) in rapeseed. More specifically, the T3 treatment significantly decreased the infection rate of these two diseases mentioned above by an average of $17.33 \%$ and $12.14 \%$ in two years compared to the CK, respectively. Therefore, the study and application of wood vinegar due to its compound effects on crop growth and yield is of great importance to sustainable agriculture, crop ecology, and environmental protection.

Keywords: Brassica napus; wood vinegar; growth regulator; foliar spray; yield; quality; resistance

\section{Introduction}

Rapeseed is the fourth largest crop after rice, corn, and wheat, and it is also the essential raw material for edible oil grown in China. However, compared with some high-yield countries in Europe, our country's oil production is relatively low [1]. Therefore, Chinese scientists have been committed to coordinating the environment and cultivation measures to increase the yield of rapeseed in recent years. Among them, the application of plant growth regulators is an important control measure to achieve robust growth and a high yield of rapeseed [2].

There are more than 30 kinds of plant growth regulators currently allowed in China. They can be divided into three categories according to their functions: plant growth 
promoters, retarders, and inhibitors. Among them, promotion and retardation are commonly used. Accelerators include naphthalene acetic acid (NAA), gibberellins (GAs), 6-benzylaminopurine (6-BA), and brassinolide (BR) [2,3]. These regulators accelerate plant growth by promoting organ development, enhancing leaf photosynthetic capacity, and boosting dry matter formation $[4,5]$. Retarders include paclobutrazol, chlormequat chloride, and mepiquat chloride, which are mainly used to regulate the morphology of the plant under conditions of excessive vegetative growth of crops to achieve robust growth and improve stress resistance. Gibberellin is the most widely used regulator in agricultural production, which can mediate various plant growth processes, especially in promoting seed germination, stem elongation, and flowering [6]. In the past 20 years, it has been discovered that melatonin plays a vital role in improving the resistance of crops. It can also promote seed germination, rooting, and delay leaf senescence $[7,8]$. Melatonin can enhance the yield of soybeans and rapeseed by increasing leaf area, plant height, and number of pods [9]. Sodium gluconate is a kind of small-molecule organic matter with good penetration, moisture retention, and adhesion. It is usually used as a fertilizer additive in agricultural production, and mixed spraying with nutrients can promote crop growth and nutrient absorption [10]. However, it was found that sodium gluconate can promote seedling growth, enhance drought resistance, and increase chlorophyll content in cotton and rapeseed studies [11-13].

Many research studies have shown that regulation mechanisms and characteristics vary among different plant growth regulators, which need to be applied reasonably according to environmental conditions and plant status. Otherwise, the effect is not only unstable but even adverse [3,6,9]. For example, the application of gibberellin is likely to accelerate the elongation of the stalk, at the same time, make the plant shape slender [4]. Paclobutrazol will prevent the plants from growing vigorously, and their biomass will significantly decrease [2]. Besides, it is not easy to adapt to various environmental conditions simultaneously by using one regulator and comprehensively regulating and controlling crop growth in many aspects. It is necessary to mix and apply different regulators rationally.

Wood vinegar is a liquid condensed from carbonized flue gas in producing biochar from agricultural and forestry waste under high temperature and hypoxia. It is a green and environmentally friendly biomass material with sterilization and insect control effects [14-16]. The analysis shows that wood vinegar contains $10 \%-20 \%$ of organic compounds and more than 200 different types of organic compounds [17]. These organic compounds include organic acids, ketones, aldehydes, alcohols, benzene and its derivatives, heterocyclic compounds, phenols and their derivatives, alkyl phenyl ethers, carbohydrate derivatives, and nitrogen compounds [18-20]. In recent years, it has been discovered that wood vinegar can be considered as a compound plant growth regulator analogue, and wood vinegar at an appropriate concentration has a good effect on crops [21,22]. Namely, an optimal concentration of wood vinegar contains various functional substances in an appropriate proportion, which are not only beneficial to crop growth but also produce good interactions, which can promote the robust growth of crops, enhance stress resistance, disease resistance, and insect resistance, such effect can ultimately increase crop yield and quality [23]. At present, the preliminary research on the agricultural application of wood vinegar has just begun, and the crops mainly involved are rice, wheat, and tobacco. Previous studies show that wood vinegar diluted 300 times can increase yield and protein content, improve rice quality, and significantly enhance photosynthesis, panicle number, and effective tiller number $[24,25]$. Seed soaking with wood vinegar diluted by 600 times can promote the germination and growth of wheat, increase dry weight, and enhance the tolerance to drought stress [26]. Spraying tobacco with a 300-fold dilution of wood vinegar can significantly increase yield, enhance antioxidant enzyme activity, and soluble protein and potassium content.

Since the application research of wood vinegar on crops is still in the exploratory stage, few reports are available on the systematic research on the growth and development, yield, quality, and resistance of different crops. The compound effect of wood vinegar 
and other plant growth regulators has not been reported yet. Therefore, based on the preliminary screening experiment results, in this paper, a suitable concentration of wood vinegar and a combination of gibberellin, melatonin, and gluconate that have a good interaction with wood vinegar was selected for two years of field planting experiments, to study the effects of different treatments on agronomic traits, photosynthetic efficiency, low-temperature resistance, and disease incidence during the growth and development of rapeseed, provide a scientific basis for the correct promotion and application of wood vinegar, and technical support for the sustainable development of agricultural production.

\section{Materials and Methods}

\subsection{Experimental Site and Soil Characteristics}

The experiment was conducted at Huazhong Agricultural University, Wuhan, China $\left(30^{\circ} 47^{\prime} \mathrm{N}, 114^{\circ} 36^{\prime} \mathrm{E}\right)$ for two years (2018-2019 and 2019-2020). The monthly average temperature, solar radiation, and rainfall data for the rapeseed growing season were obtained from a weather station approximately $200 \mathrm{~m}$ from the experiment site (AWS800, Campbell Scientific, Inc., Logan, UT, USA). The daily average temperature in 2018-2019 and 2019-2020 was $11.53{ }^{\circ} \mathrm{C}$ and $13.01{ }^{\circ} \mathrm{C}$, respectively (Figure 1), the average daily solar radiation was $8.12 \mathrm{MJ} / \mathrm{m}^{2}$ and $9.35 \mathrm{MJ} / \mathrm{m}^{2}$, respectively, and the total amount of rainfall was $489.4 \mathrm{~mm}$ and $360.1 \mathrm{~mm}$, respectively. The soil type is silty-loam, and rice had previously been grown at the experiment site. Soil samples were collected from the $20 \mathrm{~cm}$ soil layer for analysis before the experiment was started. The $\mathrm{pH}$ of the soil was 6.47 , and the soil was composed of organic matter $16.47 \mathrm{~g} \mathrm{~kg}^{-1}$, ammonium nitrogen $24.59 \mathrm{mg} \mathrm{kg}^{-1}$, nitrate-nitrogen $23.82 \mathrm{mg} \mathrm{kg}^{-1}$, available phosphorus $14.74 \mathrm{mg} \mathrm{kg}^{-1}$, available potassium $179.60 \mathrm{mg} \mathrm{kg}^{-1}$, and sulfur $170.00 \mathrm{mg} \mathrm{kg}^{-1}$.
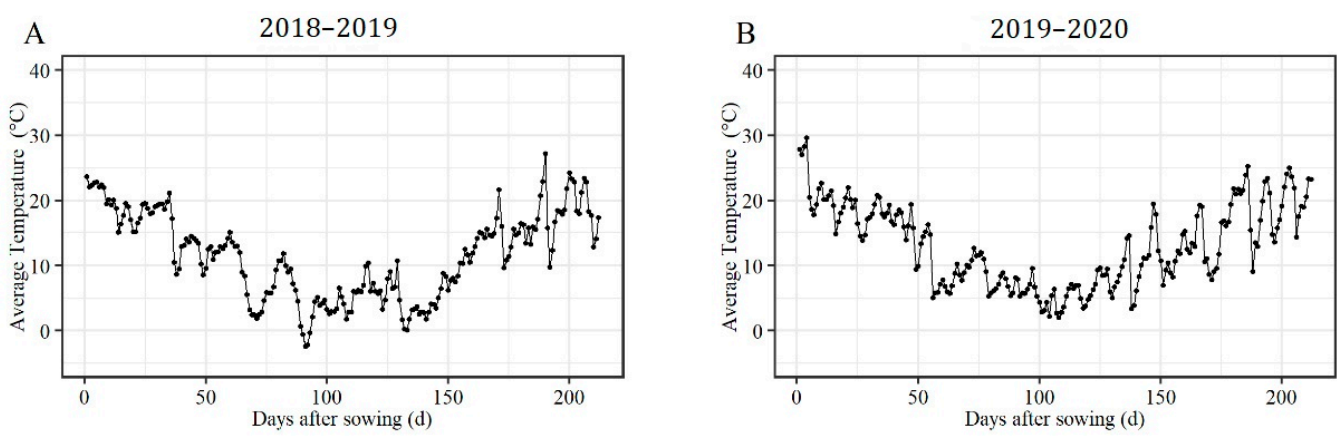

Figure 1. The daily average temperature of rapeseed after sowing in 2018-2019 (A) and 2019-2020 (B).

\subsection{Experimental Materials}

Huayuza 9, a hybrid rapeseed variety widely cultivated in the Yangtze River basin, was selected as the experimental material, and the seeds were provided by Shengguang Seed Industry Co., Ltd. (Wuhan, China).

The wood vinegar used in the experiment originated from poplar charcoal smoke and was provided by Hubei Chutian Biomass Energy Technology Development Co., Ltd. (Wuhan, China). Other plant growth regulators selected in the experiment were purchased, among them, gibberellin $\left(\mathrm{GA}_{3}\right)$ produced by Guangzhou Feiyang Bioengineering Co., Ltd. (Guangzhou, China), D-sodium gluconate produced by Sinopharmaceutical Group Chemical Reagent Co., Ltd. (Shanghai, China), and melatonin was produced by Shanghai Yuanye Biotechnology Co., Ltd. (Shanghai, China).

\subsection{Experimental Design}

Five treatments were selected based on our previous study [27] and preliminary experiment. They were the control (tap water), wood vinegar diluted 400-fold (M), a combination of 400-fold wood vinegar and $25 \mathrm{mg} \mathrm{L}^{-1}$ gibberellin (T1), 400-fold wood vinegar and 
$600 \mathrm{mg} \mathrm{L}^{-1}$ sodium D-gluconate (T2), and 400-fold wood vinegar and $25 \mathrm{mg} \mathrm{L}^{-1}$ melatonin (T3). The field experiment was a random block design that was repeated three times.

The planting area of each plot was $10 \mathrm{~m}^{2}(2 \mathrm{~m} \times 5 \mathrm{~m})$, and there was a furrow of $0.5 \mathrm{~m}$ between the two plots. The seeds were sown on 13 October 2018 and 9 October 2019, with rows spaced $25 \mathrm{~cm}$ and hand-thinned to accommodate approximately 450,000 plants $^{-1}$ at the seedling stage. The total amount of nitrogen applied was $270 \mathrm{~kg} \mathrm{ha}^{-1}$, and the ratio of nitrogen, phosphorus, and potassium was 1:0.5:0.5. A total of $900 \mathrm{~kg} \mathrm{ha}^{-1} \mathrm{~N} 15-\mathrm{P} 15-\mathrm{K} 15-\mathrm{S} 9$ compound fertilizer and $15 \mathrm{~kg} \mathrm{ha}^{-1}$ boron fertilizer was used per hectare. Fifty percent of nitrogen fertilizer, all phosphorus, potassium, and boron fertilizers were applied before sowing. A total of $289 \mathrm{~kg} \mathrm{ha}^{-1}$ urea was applied to the seedlings during the overwintering period on 7-15 December. The plots were managed using conventional cultivation measures.

Different treatments were sprayed twice at the seedling stage on 21 November and 18 January in 2018-2019 and 17 November and 9 December in 2019-2020. The treatment was sprayed at $2 \mathrm{~L} \mathrm{plot}^{-1}$. A baffle was used to cover the spraying area to avoid spraying other regions.

On 14 February 2019, while the plants were in the bud bolting stage, the low temperature was $2-6{ }^{\circ} \mathrm{C}$. Three plants were selected from each plot to investigate the physiological indices under low temperatures.

\subsection{Evaluation of Wood Vinegar Contents}

The main component of wood vinegar was measured by gas chromatography-mass spectrometer (GCMS-QP2010 Shimadzu, Kyoto, Japan). Pure helium was used as a carrier gas for constant flow at the rate of $1.2 \mathrm{~mL} \mathrm{~min}^{-1}$. DB-wax capillary column ( $30 \mathrm{~m} \times 0.25 \mathrm{~mm} \times 0.25 \mu \mathrm{m}$ film thickness) was used for separation. The inlet temperature was $280{ }^{\circ} \mathrm{C}$. The column temperature was maintained at $60^{\circ} \mathrm{C}$ for $2 \mathrm{~min}$, increased to $240{ }^{\circ} \mathrm{C}$ at a rate of $6^{\circ} \mathrm{C} \mathrm{min}-1$, and maintained for $8 \mathrm{~min}$. It was carried out at a fractional injection rate of 80:1. The mass spectrometry conditions were maintained as electron energy was $70 \mathrm{ev}$, the ion source temperature was $250{ }^{\circ} \mathrm{C}$, and the scan range of the mass spectrum was $35-400 \mathrm{~m} \mathrm{z}^{-1}$. Compounds were identified by the retention time and comparison of mass spectrometry and mass spectral library data (NIST). The relative peak area was used to measure the content of the compound [20].

\subsection{Measurement of Morphological Indices}

After foliar spraying, five plants were collected to measure fresh weight, total leaves number, and green leaves number from each plot at the seedling stage (56 days after sowing), bud bolting stage (128 days after sowing), flowering stage (164 days after sowing), and pod stage (182 days after sowing). The height of plant was determined using a ruler to measure the distance from the cotyledon node to the top of the plant. The diameter of the neck was measured with a Vernier calliper. The leaf area index (LAI) was calculated using a SUNSACN Canopy Analysis System (Delta-T Devices, Cambridge, UK) at the seedling, bud bolting, and flowering stage of rapeseed in six repetitions in each treatment. The pod area index (PAI) is measured in the pod stage of rapeseed. The SSI probe of the system was placed horizontally perpendicular to the base of the rapeseed direction to collect canopy data from 10:30-14:30 in sunny and stable weather. Nine rapeseed plants at the same stage of growth were selected for the evaluation of dry matter mass. The plants were cleaned and de-greened at $105^{\circ} \mathrm{C}$ for $30 \mathrm{~min}$. The temperature was adjusted to $75^{\circ} \mathrm{C}$ to obtain the constant weight of rapeseed. The dry biomass was weighed to obtain the average value of 10 plants.

\subsection{SPAD Measurement}

The SPAD value was measured using a SPAD-502 (Minolta, Osaka, Japan) at 10:00 on a clear and cloudless morning. The inverted four functional leaves of rapeseed (the fourth completely flattened leaf from top to bottom) were selected to avoid the veins. The SPAD 
values were measured six times in different parts of the same leaf, and the average value was calculated and repeated six times.

\subsection{Assessment of Photosynthetic Parameters}

The net photosynthetic rate and stomatal conductance of rapeseed leaves were measured using a Li-Cor 6400XT (Li-COR Inc., Lincoln, NE, USA) portable photosynthesis instrument, measure the fourth last functional leaf of rapeseed in the clear and cloudless weather from 9:00 to 11:00. The control of leaf chamber light intensity was $1000 \mu \mathrm{mol} \mathrm{m}^{-2} \mathrm{~s}^{-1}$. The leaf temperature was $25^{\circ} \mathrm{C}$, and the air vapor pressure deficit (VPD) was $1.2-1.8 \mathrm{kPa}$ for six times.

\subsection{Investigation of Soluble Protein, Chlorophyll, Malondialdehyde, Proline, Superoxide Dismutase, Peroxidase, and Catalase}

Soluble protein was determined using Coomassie brilliant blue with bovine serum albumin as the standard [28]. The chlorophyll was extracted using $95 \%$ ethanol, and the content was measured [29]. The content of malondialdehyde (MDA) was measured using the thiobarbituric acid method [30]. The content of proline was measured using the ninhydrin method [31]. The activities of superoxide dismutase (SOD), peroxidase (POD), and catalase (CAT) were measured using the WST-1 method, colorimetry, and UV-Vis spectrophotometry, respectively [32]. The reagents were provided by the Nanjing Jiancheng Biotechnology Co., Ltd. (Nanjing, China).

\subsection{Determination of Yield Components and Quality Indices}

The plants were sampled when approximately two-thirds of the rapeseed seeds were brown on 4 May 2019 and 1 May 2020, such as plant height, root neck diameter, number of effective branches, number of effective pods, number of seeds per pod, and 1000-seed weight, and each part of the plant was weighed after air drying. The yield of the seed was measured after each plot was singly harvested and dried. The harvested rapeseed was dried until the water content was less than $10 \%$. The near-infrared analyzer (NIRSystem3750, Stockholm, Sweden) was used to determine the contents of oil, protein, and glucosinolate.

\subsection{Assessment of Sclerotinia Sclerotiorum and Peronospora Parasitica}

Thirty plants in the rapeseed pod stage were sampled at five diagonal points in each plot, and the number of diseased plants were measured. Disease incidence assessments were conducted on 150 plants in each plot and the diseased plants were identified on the base of the morphological characteristics of Sclerotinia sclerotiorum and Peronospora parasitica [33].

\subsection{Data Processing and Statistical Analysis}

Shapiro-Wilk test for normality hypothesis was conducted, and the result showed that the data conforms to the normal distribution. Analysis of variance (ANOVA) among growing seasons (2018-2019 and 2019-2020) and treatments (CK, M, T1, T2, T3) was performed using Statistix 9.0 software (Analytical Software, Tallahassee, FL, USA). Differences in treatment means were compared by the LSD test $(p<0.05)$. Graphics were drawn using R 4.0.1 (http:/ / www.r-project.org/ (accessed on 2 January 2021)).

\section{Results}

\subsection{Wood Vinegar Mainly Contains Phenols and Organic Acids}

To measure the composition of wood vinegar, we adopted the method of GC-MS. A total of 54 organic substances with relative content greater than $0.07 \%$ were observed in the wood vinegar liquor (Table 1). Among them, the highest relative content of the phenols and derivatives was $43.19 \%$, followed by organic acids $26.97 \%$, ketones $10.53 \%$, and esters $3.85 \%$, furan derivatives $1.48 \%$, alkanes compound $3.36 \%$, aldehydes $1.72 \%$, and nitrogen compounds $1.46 \%$. 
Table 1. Main components of wood vinegar.

\begin{tabular}{|c|c|c|c|c|}
\hline Retention Time (min) & Compounds & Relative Content (\%) & Formula & $\begin{array}{c}\text { Molar Mass } \\
\left(\mathrm{g} \mathrm{mol}^{-1}\right)\end{array}$ \\
\hline & Organic acids & 26.97 & & \\
\hline 1.93 & Formic acid & 0.39 & $\mathrm{CH}_{2} \mathrm{O}_{2}$ & 46 \\
\hline 3.16 & Acetic acid & 22.99 & $\mathrm{C}_{2} \mathrm{H}_{4} \mathrm{O}_{2}$ & 60 \\
\hline 4.76 & Propanoic acid & 0.38 & $\mathrm{C}_{3} \mathrm{H}_{6} \mathrm{O}_{2}$ & 74 \\
\hline 5.59 & 2-Hydroxy-2-met-propanoic acid & 0.11 & $\mathrm{C}_{5} \mathrm{H}_{10} \mathrm{O}_{3}$ & 118 \\
\hline 9.93 & Butyric acid & 2.55 & $\mathrm{C}_{4} \mathrm{H}_{8} \mathrm{O}_{2}$ & 88 \\
\hline \multirow[t]{2}{*}{7.21} & 2-Oxo-n-valericacid & 0.55 & $\mathrm{C}_{5} \mathrm{H}_{8} \mathrm{O}_{3}$ & 116 \\
\hline & Ketones & 10.53 & & \\
\hline 2.24 & 2-Butanone & 0.37 & $\mathrm{C}_{4} \mathrm{H}_{8} \mathrm{O}$ & 72 \\
\hline 3.58 & Acetoin & 0.3 & $\mathrm{C}_{4} \mathrm{H}_{8} \mathrm{O}_{2}$ & 88 \\
\hline 4.8 & 1-Hydroxy-2-butanone & 0.28 & $\mathrm{C}_{4} \mathrm{H}_{8} \mathrm{O}_{2}$ & 88 \\
\hline 5.31 & Cyclopentanone & 0.62 & $\mathrm{C}_{5} \mathrm{H}_{8} \mathrm{O}$ & 84 \\
\hline 6.15 & 1-Hydroxy-3-methyl-2-butanone & 0.21 & $\mathrm{C}_{5} \mathrm{H}_{10} \mathrm{O}_{2}$ & 102 \\
\hline 6.5 & 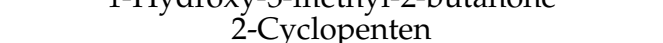 & 1.61 & $\mathrm{C}_{5} \mathrm{H}_{6} \mathrm{O}$ & 82 \\
\hline 8.81 & 2-Methyl-2-cyclopenten-1-one & 1.44 & $\mathrm{C}_{6} \mathrm{H}_{8} \mathrm{O}$ & 96 \\
\hline 12.47 & 2,5-Dihydro-3,5-dimeth-2-furanone & 0.66 & $\mathrm{C}_{6} \mathrm{H}_{8} \mathrm{O}_{2}$ & 112 \\
\hline 13.8 & 2,3-Dimeth-2-cyclopenten-1-one & 1.25 & $\mathrm{C}_{7} \mathrm{H}_{10} \mathrm{O}$ & 110 \\
\hline 13.96 & 3-Methyl-1,2-cyclopentanedione & 1.14 & $\mathrm{C}_{6} \mathrm{H}_{8} \mathrm{O}_{2}$ & 112 \\
\hline 15.85 & 3-Ethyl-2-methyl-2-cyclopenten-1-one & 0.22 & $\mathrm{C}_{7} \mathrm{H}_{10} \mathrm{O}_{2}$ & 126 \\
\hline 20.48 & 2-Hydroxy-3-propyl-2-cyclopenten-1-one & 0.38 & $\mathrm{C}_{8} \mathrm{H}_{12} \mathrm{O}_{2}$ & 140 \\
\hline 29.38 & 1-(4-Hydroxy-3-methoxyphenyl)-ethanone & 0.48 & $\mathrm{C}_{9} \mathrm{H}_{10} \mathrm{O}_{3}$ & 166 \\
\hline 30.66 & 1-(4-Hydroxy-3-methoxyphenyl)-2-propanone & 1.29 & $\mathrm{C}_{10} \mathrm{H}_{12} \mathrm{O}_{3}$ & 180 \\
\hline \multirow[t]{2}{*}{36.34} & 1-(4-Hydroxy-3,5-dimethoxyphenyl)-ethanone & 0.28 & $\mathrm{C}_{10} \mathrm{H}_{12} \mathrm{O}_{4}$ & 196 \\
\hline & Esters & 3.85 & & \\
\hline 2.37 & Ethylacetate & 0.67 & $\mathrm{C}_{4} \mathrm{H}_{8} \mathrm{O}_{2}$ & 88 \\
\hline 9.24 & Gamma-butyrolactone & 2.34 & $\mathrm{C}_{4} \mathrm{H}_{6} \mathrm{O}_{2}$ & 86 \\
\hline 11.32 & Methyl2-furoate & 0.09 & $\mathrm{C}_{6} \mathrm{H}_{6} \mathrm{O}_{3}$ & 126 \\
\hline \multirow[t]{2}{*}{14.73} & 2,6-Dimethyl-1-cyclohexen-1-ylacetate & 0.75 & $\mathrm{C}_{10} \mathrm{H}_{16} \mathrm{O}_{2}$ & 168 \\
\hline & Furan derivatives & 1.48 & & \\
\hline 5.51 & Tetrahydro-2-furanol & 0.41 & $\mathrm{C}_{4} \mathrm{H}_{8} \mathrm{O}_{2}$ & 88 \\
\hline 4.33 & 2-Methoxytetrahydrofuran & 0.19 & $\mathrm{C}_{5} \mathrm{H}_{10} \mathrm{O}_{2}$ & 102 \\
\hline \multirow[t]{2}{*}{8.98} & 1-(2-Furanyl)-ethanone & 0.88 & $\mathrm{C}_{6} \mathrm{H}_{6} \mathrm{O}_{2}$ & 110 \\
\hline & Alkanes compounds & 3.36 & & \\
\hline 5.79 & Methoxymethyl-oxirane & 0.07 & $\mathrm{C}_{4} \mathrm{H}_{8} \mathrm{O}_{2}$ & 88 \\
\hline 9.17 & 3-Bromo-pentane & 0.59 & $\mathrm{C}_{5} \mathrm{H}_{11} \mathrm{Br}$ & 150 \\
\hline \multirow[t]{2}{*}{15.63} & Bicyclo [2.2.2] octane & 2.7 & $\mathrm{C}_{8} \mathrm{H}_{14}$ & 110 \\
\hline & Aldehydes & 1.72 & & \\
\hline 10.85 & 5-Methyl-2-furancarboxaldehyde & 0.19 & $\mathrm{C}_{6} \mathrm{H}_{6} \mathrm{O}_{2}$ & 110 \\
\hline \multirow[t]{2}{*}{26.77} & Vanillin & 1.53 & $\mathrm{C}_{8} \mathrm{H}_{8} \mathrm{O}_{3}$ & 152 \\
\hline & Phenols and derivatives & 43.19 & & \\
\hline 11.95 & Phenol & 5.91 & $\mathrm{C}_{6} \mathrm{H}_{6} \mathrm{O}$ & 94 \\
\hline 14.64 & O-cresol & 2.41 & $\mathrm{C}_{7} \mathrm{H}_{8} \mathrm{O}$ & 108 \\
\hline 15.48 & 3-Methylphenol & 3.74 & $\mathrm{C}_{7} \mathrm{H}_{8} \mathrm{O}$ & 108 \\
\hline 15.73 & Guaiacol & 2.75 & $\mathrm{C}_{7} \mathrm{H}_{8} \mathrm{O}_{2}$ & 124 \\
\hline 18.03 & 2,4-Dimethylphenol & 0.89 & $\mathrm{C}_{8} \mathrm{H}_{10} \mathrm{O}$ & 122 \\
\hline 18.11 & 2,5-Dimethylphenol & 0.39 & $\mathrm{C}_{8} \mathrm{H}_{10} \mathrm{O}$ & 122 \\
\hline 18.65 & 4-Ethyl-phenol & 0.47 & $\mathrm{C}_{8} \mathrm{H}_{10} \mathrm{O}$ & 122 \\
\hline 18.82 & 3,5-Dimethylphenol & 0.37 & $\mathrm{C}_{8} \mathrm{H}_{10} \mathrm{O}$ & 122 \\
\hline 19.03 & 2,3-Dimethylphenol & 0.22 & $\mathrm{C}_{8} \mathrm{H}_{10} \mathrm{O}$ & 122 \\
\hline 19.5 & 2-Methoxy-4-methylphenol & 2.04 & $\mathrm{C}_{8} \mathrm{H}_{10} \mathrm{O}_{2}$ & 138 \\
\hline 19.6 & 3,4-Dimethylphenol & 0.27 & $\mathrm{C}_{8} \mathrm{H}_{10} \mathrm{O}$ & 122 \\
\hline 20.01 & Catechol & 8.95 & $\mathrm{C}_{6} \mathrm{H}_{6} \mathrm{O}_{2}$ & 110 \\
\hline 22.07 & 4-Methyl-1,2-benzenediol & 4.81 & $\mathrm{C}_{7} \mathrm{H}_{8} \mathrm{O}_{2}$ & 124 \\
\hline 22.51 & 4-Ethyl-2-methoxyphenol & 1.32 & $\mathrm{C}_{9} \mathrm{H}_{12} \mathrm{O}_{2}$ & 152 \\
\hline 25.14 & 2,6-Dimethoxy-phenol & 3.56 & $\mathrm{C}_{8} \mathrm{H}_{10} \mathrm{O}_{3}$ & 154 \\
\hline 25.23 & 2,5-Dimethyl-1,4-benzenediol & 0.9 & $\mathrm{C}_{8} \mathrm{H}_{10} \mathrm{O}_{2}$ & 138 \\
\hline 25.37 & 3,4-Dimethoxy-phenol & 0.29 & $\mathrm{C}_{8} \mathrm{H}_{10} \mathrm{O}_{3}$ & 154 \\
\hline 26.29 & 4-Ethylcatechol & 1.8 & $\mathrm{C}_{8} \mathrm{H}_{10} \mathrm{O}_{2}$ & 138 \\
\hline 28.13 & 1,2,4-Trimethoxvbenzene & 1.65 & $\mathrm{C}_{9} \mathrm{H}_{12} \mathrm{O}_{3}$ & 168 \\
\hline \multirow[t]{2}{*}{30.44} & 1,2,3-Trimethoxy-5-methyl-benzene & 0.45 & $\mathrm{C}_{10} \mathrm{H}_{14} \mathrm{O}_{3}$ & 182 \\
\hline & Nitrogen compounds & 1.46 & & \\
\hline 21.93 & Pyridine & 1.46 & $\mathrm{C}_{5} \mathrm{H}_{5} \mathrm{~N}$ & 79 \\
\hline
\end{tabular}




\subsection{Wood Vinegar and Its Compounds with Three Regulating Substances Can Increase Rapeseed Yield}

The yield and its components were measured to study the application effects of these four treatments on rapeseed. The results of field experiments during the two years exhibited the same trend. Table 2 shows that the seed yield of $\mathrm{M}$ was increased by $9.58 \%$ on average, over CK in both years. Besides, the seed yield of $\mathrm{T} 1, \mathrm{~T} 2$, and $\mathrm{T} 3$ increased by an average of $7.88 \%, 6.90 \%$, and $1.32 \%$ compared to $\mathrm{M}$ in two years, respectively. Combination $\mathrm{T} 1$ was the most effective treatment. A comparison of yield components indicated that the application of wood vinegar and its different combinations significantly increased the effective number of branches, the effective number of pods, and the 1000-seed weight of the main stem and branches. The number of effective pods per plant and seeds per pod of the $\mathrm{M}$ treatment increased by an average of $23.80 \%$ and $9.80 \%$ in two years, respectively, compared to the CK. The number of effective pods per plant and seeds per pod of treatments T1, T2, and T3 was higher than those of $\mathrm{M}$. The yield of the $\mathrm{T} 1$ treatment increased by an average of $32.88 \%$ in two years, respectively, compared to $\mathrm{M}$. The application of wood vinegar significantly increased the seed yield of rapeseed primarily by improving the number of effective pods per plant and the number of seeds per pod. The combination of gibberellin, D-sodium gluconate, melatonin, and wood vinegar could further enhance the positive effect of wood vinegar, and the gibberellin treatment was the most effective at raising seed yield.

Table 2. Effects of four treatments on the yield and components of rapeseed.

\begin{tabular}{|c|c|c|c|c|c|c|c|c|c|}
\hline Year & Treatment & $\begin{array}{l}\text { Branch } \\
\text { Number } \\
\text { Per Plant }\end{array}$ & $\begin{array}{c}\text { Pods } \\
\text { Number } \\
\text { on the } \\
\text { Main } \\
\text { Stem }\end{array}$ & $\begin{array}{c}\text { Branch } \\
\text { Pods } \\
\text { Number } \\
\text { Per Plant }\end{array}$ & $\begin{array}{c}\text { Pods } \\
\text { Number } \\
\text { Per Plant }\end{array}$ & $\begin{array}{l}\text { Seeds } \\
\text { Number } \\
\text { Per Pod }\end{array}$ & $\begin{array}{c}\text { Seed } \\
\text { Weight } \\
(g / 1000)\end{array}$ & $\begin{array}{l}\text { Yield Per } \\
\text { Plant (g) }\end{array}$ & $\begin{array}{c}\text { Total } \\
\text { Yield } \\
\left(\mathbf{k g ~ h a}^{-1}\right)\end{array}$ \\
\hline \multirow{6}{*}{ 2018-2019 } & CK & $4.20 \mathrm{c}$ & $69.07 \mathrm{~b}$ & $87.37 \mathrm{~d}$ & $156.43 \mathrm{c}$ & $17.25 \mathrm{~b}$ & $2.85 \mathrm{a}$ & $13.00 \mathrm{c}$ & $1967.60 \mathrm{c}$ \\
\hline & $\mathrm{M}$ & $6.20 \mathrm{~b}$ & $71.83 \mathrm{~b}$ & 137.77 c & $209.60 \mathrm{~b}$ & $20.13 \mathrm{ab}$ & $2.88 \mathrm{a}$ & $14.96 \mathrm{~b}$ & $2172.40 \mathrm{~b}$ \\
\hline & $\mathrm{T} 1$ & $9.27 \mathrm{a}$ & $88.30 \mathrm{a}$ & 206.60 a & $294.90 \mathrm{a}$ & $20.56 \mathrm{a}$ & $2.97 \mathrm{a}$ & $17.25 \mathrm{a}$ & $2375.10 \mathrm{a}$ \\
\hline & $\mathrm{T} 2$ & $6.87 \mathrm{~b}$ & $81.23 \mathrm{a}$ & $164.37 \mathrm{~b}$ & $245.60 \mathrm{ab}$ & $20.91 \mathrm{a}$ & $2.85 \mathrm{a}$ & $16.46 \mathrm{ab}$ & $2340.80 \mathrm{ab}$ \\
\hline & $\mathrm{T} 3$ & $7.80 \mathrm{ab}$ & $86.27 \mathrm{a}$ & $181.90 \mathrm{ab}$ & $268.17 \mathrm{ab}$ & $20.03 \mathrm{ab}$ & $2.86 \mathrm{a}$ & $16.06 \mathrm{ab}$ & $2218.30 \mathrm{ab}$ \\
\hline & Mean & $6.87 \mathrm{~A}$ & $79.34 \mathrm{~A}$ & $172.66 \mathrm{~A}$ & $234.94 \mathrm{~A}$ & $19.78 \mathrm{~B}$ & $2.88 \mathrm{~A}$ & $15.55 \mathrm{~A}$ & $2214.84 \mathrm{~A}$ \\
\hline \multirow{5}{*}{ 2019-2020 } & CK & $6.40 \mathrm{a}$ & $65.60 \mathrm{a}$ & $118.56 \mathrm{~b}$ & $184.16 \mathrm{~b}$ & $22.07 \mathrm{c}$ & $2.83 \mathrm{a}$ & $11.50 \mathrm{c}$ & $2001.70 \mathrm{~b}$ \\
\hline & $\mathrm{M}$ & $7.20 \mathrm{a}$ & $66.90 \mathrm{a}$ & $142.32 \mathrm{ab}$ & $209.22 \mathrm{ab}$ & $22.71 \mathrm{c}$ & $2.85 \mathrm{a}$ & $13.54 \mathrm{bc}$ & $2176.70 \mathrm{ab}$ \\
\hline & $\mathrm{T} 1$ & $7.20 \mathrm{a}$ & $71.70 \mathrm{a}$ & $164.16 \mathrm{a}$ & $235.86 \mathrm{a}$ & $28.40 \mathrm{a}$ & $2.91 \mathrm{a}$ & $19.49 \mathrm{a}$ & $2316.70 \mathrm{a}$ \\
\hline & $\mathrm{T} 2$ & $6.72 \mathrm{a}$ & $68.13 \mathrm{a}$ & $156.37 \mathrm{ab}$ & $224.50 \mathrm{a}$ & $27.08 \mathrm{a}$ & $2.90 \mathrm{a}$ & $17.63 \mathrm{ab}$ & $2308.30 \mathrm{a}$ \\
\hline & T3 & $6.56 \mathrm{a}$ & $69.40 \mathrm{a}$ & $147.41 \mathrm{ab}$ & $216.81 \mathrm{a}$ & $24.97 \mathrm{~b}$ & $2.90 \mathrm{a}$ & $15.70 \mathrm{~b}$ & $2188.30 \mathrm{ab}$ \\
\hline \multirow{4}{*}{ VA } & Mean & $6.82 \mathrm{~A}$ & 68.35 B & $145.76 \mathrm{~A}$ & $214.11 \mathrm{~A}$ & $25.05 \mathrm{~A}$ & $2.88 \mathrm{~A}$ & $15.57 \mathrm{~A}$ & $2198.34 \mathrm{~A}$ \\
\hline & $\mathrm{Y}$ & ns & $* *$ & ns & ns & $* *$ & ns & ns & ns \\
\hline & $\mathrm{T}$ & $*$ & * & $* *$ & $* *$ & ** & ns & $* *$ & $*$ \\
\hline & $\mathrm{T} \times \mathrm{Y}$ & ns & * & * & $*$ & ns & ns & * & ns \\
\hline
\end{tabular}

Note: Lowercase and uppercase letters after each column of numbers indicate a significant difference at level 0.05 according to the LSD test comparison among each treatment in one year and all treatments between two growing seasons, respectively. T $\times \mathrm{Y}$, treatment $\times$ year. ns denotes non-significance at the 0.05 level. ${ }^{*} p<0.05$. ${ }^{* *} p<0.01$. CK, control. M, wood vinegar diluted 400-fold. T1, M mixed with gibberellin. T2, M mixed with sodium D-gluconate. T3, M mixed with melatonin.

Determination of rapeseed quality by Near-Infrared Analyzer. Table 3 shows that wood vinegar and its compounds with three regulating substances tended to reduce the content of glucosinolate compared to the CK. Among them, the glucosinolate content of T2 and T3 decreased by an average of $12.83 \%$ and $6.72 \%$ in two years, respectively, compared to the CK. The effects of four treatments on the contents of oil, protein, linolenic acid, linoleic acid, and oleic acid in rapeseed did not differ significantly from those of the CK. 
Table 3. Effects of four treatments on the quality of rapeseed.

\begin{tabular}{|c|c|c|c|c|c|c|c|}
\hline Year & Treatment & $\begin{array}{c}\text { Oil Content } \\
(\%)\end{array}$ & $\begin{array}{c}\text { Protein } \\
\text { Content (\%) }\end{array}$ & $\begin{array}{l}\text { Glucosinolate } \\
\text { (umole/g) }\end{array}$ & $\begin{array}{l}\text { Linolenic } \\
\text { Acid (\%) }\end{array}$ & $\begin{array}{l}\text { Linoleic } \\
\text { Acid (\%) }\end{array}$ & $\begin{array}{l}\text { Oleic Acid } \\
(\%)\end{array}$ \\
\hline 2018- & CK & $44.80 \mathrm{a}$ & $18.92 \mathrm{~b}$ & $24.91 \mathrm{a}$ & $6.47 \mathrm{a}$ & $16.90 \mathrm{a}$ & $67.50 \mathrm{a}$ \\
\hline \multirow[t]{5}{*}{2019} & $\mathrm{M}$ & $44.31 \mathrm{a}$ & $21.13 \mathrm{a}$ & $24.00 \mathrm{ab}$ & $7.05 \mathrm{a}$ & $16.80 \mathrm{a}$ & $66.88 \mathrm{a}$ \\
\hline & $\mathrm{T} 1$ & $44.75 \mathrm{a}$ & $19.49 \mathrm{ab}$ & $23.60 \mathrm{ab}$ & $6.51 \mathrm{a}$ & $17.08 \mathrm{a}$ & $67.00 \mathrm{a}$ \\
\hline & $\mathrm{T} 2$ & $44.91 \mathrm{a}$ & $19.17 \mathrm{ab}$ & $21.41 \mathrm{~b}$ & $6.26 \mathrm{a}$ & $17.15 \mathrm{a}$ & $68.00 \mathrm{a}$ \\
\hline & T3 & $45.10 \mathrm{a}$ & $19.40 \mathrm{ab}$ & $22.81 \mathrm{~b}$ & $6.62 \mathrm{a}$ & $17.49 \mathrm{a}$ & $66.62 \mathrm{a}$ \\
\hline & Mean & 44.77 B & $19.62 \mathrm{~A}$ & $23.35 \mathrm{~B}$ & $6.58 \mathrm{~B}$ & $17.08 \mathrm{~B}$ & $67.20 \mathrm{~A}$ \\
\hline 2019- & CK & $46.59 \mathrm{a}$ & $17.79 \mathrm{a}$ & $31.57 \mathrm{a}$ & $7.08 \mathrm{a}$ & $17.47 \mathrm{a}$ & $69.08 \mathrm{a}$ \\
\hline \multirow[t]{5}{*}{2020} & $\mathrm{M}$ & $47.04 \mathrm{a}$ & $17.73 \mathrm{a}$ & $30.93 \mathrm{a}$ & $7.22 \mathrm{a}$ & $17.54 \mathrm{a}$ & $66.98 \mathrm{a}$ \\
\hline & $\mathrm{T} 1$ & $47.99 \mathrm{a}$ & $17.78 \mathrm{a}$ & $30.48 \mathrm{ab}$ & $7.27 \mathrm{a}$ & $17.88 \mathrm{a}$ & $66.65 \mathrm{a}$ \\
\hline & $\mathrm{T} 2$ & $47.99 \mathrm{a}$ & $17.58 \mathrm{a}$ & $28.05 \mathrm{~b}$ & $7.32 \mathrm{a}$ & $17.84 \mathrm{a}$ & $68.24 \mathrm{a}$ \\
\hline & T3 & $46.49 \mathrm{a}$ & $18.40 \mathrm{a}$ & $29.99 \mathrm{~b}$ & $7.48 \mathrm{a}$ & $18.36 \mathrm{a}$ & $66.70 \mathrm{a}$ \\
\hline & Mean & $47.22 \mathrm{~A}$ & $17.86 \mathrm{~B}$ & $30.20 \mathrm{~A}$ & $7.27 \mathrm{~A}$ & $17.82 \mathrm{~A}$ & $67.53 \mathrm{~A}$ \\
\hline ANO & $\mathrm{Y}$ & $* *$ & $* *$ & $* *$ & $* *$ & $* *$ & ns \\
\hline \multirow[t]{2}{*}{ VA } & $\mathrm{T}$ & ns & ns & $* *$ & ns & ns & ns \\
\hline & $\mathrm{T} \times \mathrm{Y}$ & ns & $*$ & $*$ & ns & ns & ns \\
\hline
\end{tabular}

Note: Lowercase and uppercase letters after each column of numbers indicate a significant difference at level 0.05 according to the LSD test comparison among each treatment in one year and all treatments between two growing seasons, respectively. T $\times \mathrm{Y}$, treatment $\times$ year. ns denotes non-significance at the 0.05 level. ${ }^{*} p<0.05$. ${ }^{* *} p<0.01$.

\subsection{Effect of Wood Vinegar and Its Compounds with Three Regulating Substances on the Morphology of Rapeseed}

The morphological changes of rapeseed during the seedling, bud bolting, flowering, and pod stages were measured to clarify the effects of the four treatments at each growth stage of rapeseed. The results indicated that plant height and root collar diameter increased rapidly after entering the bud bolting stage, and the plant height of all the compound treatments was higher than that of the $M$ treatment. The increase in the T1 treatment was the highest at the bud bolting stage (Table 4). The plant height increased further with the addition of gibberellin. The root neck diameter of rapeseed reached its maximum at the flowering stage and tended to decline at the pod stage. Compared to the CK at the seedling, bud bolting, flowering, and pod stages, the root neck diameter of rapeseed treated with $\mathrm{M}$ increased by an average of $14.10 \%, 17.51 \%, 12.19 \%$, and $9.50 \%$ in two years, respectively. Promoting stem thickening and growth from the seedling to the flowering stages weakened gradually during the later growth period. The root neck diameter of compounds T1, T2, and T3 was higher than that of $\mathrm{M}$ at the seedling, bud bolting, flowering, and pod stages, and the root neck diameter of compound T1 at the bud bolting and flowering stages increased by an average of $9.73 \%$ and $9.09 \%$ in two years compared to the CK, respectively. The dual effect of adding gibberellin in the wood vinegar solution increased the stem height and thickness during the rapid growth period. However, this effect was weaker in the maturity stage, although the addition of sodium gluconate and melatonin still increased the plant height and root neck diameter at the mature stage.

Different treatments tended to increase the total leaf number and green leaf number of rapeseed (Table 5), particularly in the pod stage. The total leaf number of $M$ treatment was an average of 0.93 in two years more than that of the CK during the pod stage, and there were significant differences between the T1, T2, and T3 treatments with the $\mathrm{CK}$. The combination of wood vinegar and melatonin most effectively increased the total leaf number. The number of green leaves of the M, T1, T2, and T3 treatments was higher than that of the $C K$, and there was a significant difference between the $M$ treatment in the pod stage with the CK. The number of green leaves at the pod stage was an average of 3.04 in two years higher than that of the CK. Secondly, there was a significant difference between wood vinegar, melatonin treatment, and control. These results showed that wood vinegar and its compounds tended to increase the number of total leaves and green leaves, primarily to delay plant senescence and raise the number of green leaves in the pod stage. 
Table 4. Effects of four treatments on the plant height and root collar diameter of rapeseed.

\begin{tabular}{|c|c|c|c|c|c|c|c|c|c|}
\hline \multirow[b]{2}{*}{ Year } & \multirow[b]{2}{*}{ Treatment } & \multicolumn{4}{|c|}{ Plant Height (cm) } & \multicolumn{4}{|c|}{ Root Collar Diameter (mm) } \\
\hline & & $\begin{array}{l}\text { Seedling } \\
\text { Stage }\end{array}$ & $\begin{array}{c}\text { Bolting } \\
\text { Stage }\end{array}$ & $\begin{array}{l}\text { Flowering } \\
\text { Stage }\end{array}$ & $\begin{array}{l}\text { Pod } \\
\text { Stage }\end{array}$ & $\begin{array}{l}\text { Seedling } \\
\text { Stage }\end{array}$ & $\begin{array}{l}\text { Bolting } \\
\text { Stage }\end{array}$ & $\begin{array}{l}\text { Flowering } \\
\text { Stage }\end{array}$ & $\begin{array}{l}\text { Pod } \\
\text { Stage }\end{array}$ \\
\hline 2018- & CK & $11.56 \mathrm{a}$ & $27.67 \mathrm{~b}$ & $152.56 \mathrm{~b}$ & $159.89 \mathrm{c}$ & $4.57 \mathrm{~b}$ & $8.60 \mathrm{c}$ & $10.68 \mathrm{a}$ & $11.44 \mathrm{~b}$ \\
\hline \multirow[t]{5}{*}{2019} & M & $12.11 \mathrm{a}$ & $29.56 \mathrm{~b}$ & $159.00 \mathrm{~b}$ & $168.06 \mathrm{bc}$ & $5.53 \mathrm{a}$ & $10.59 \mathrm{ab}$ & $12.75 \mathrm{a}$ & $13.25 \mathrm{ab}$ \\
\hline & $\mathrm{T} 1$ & $12.44 \mathrm{a}$ & $44.33 \mathrm{a}$ & $170.00 \mathrm{a}$ & $175.17 \mathrm{a}$ & $5.94 \mathrm{a}$ & $11.91 \mathrm{a}$ & $14.27 \mathrm{a}$ & $14.33 \mathrm{a}$ \\
\hline & $\mathrm{T} 2$ & $12.44 \mathrm{a}$ & $35.56 \mathrm{ab}$ & $165.50 \mathrm{ab}$ & $173.00 \mathrm{ab}$ & $5.87 \mathrm{a}$ & $11.35 \mathrm{ab}$ & $13.38 \mathrm{a}$ & $14.33 \mathrm{a}$ \\
\hline & T3 & $12.11 \mathrm{a}$ & $32.11 \mathrm{~b}$ & $161.83 \mathrm{ab}$ & $172.50 \mathrm{~b}$ & $5.80 \mathrm{a}$ & $11.10 \mathrm{~b}$ & $12.95 \mathrm{a}$ & $13.65 \mathrm{a}$ \\
\hline & Mean & $12.13 \mathrm{~B}$ & $33.85 \mathrm{~A}$ & $161.78 \mathrm{~A}$ & $169.72 \mathrm{~A}$ & $5.54 \mathrm{~A}$ & $10.71 \mathrm{~A}$ & $12.81 \mathrm{~A}$ & $13.40 \mathrm{~B}$ \\
\hline 2019- & CK & $12.67 \mathrm{a}$ & $25.00 \mathrm{~b}$ & $142.33 \mathrm{~b}$ & $165.86 \mathrm{~b}$ & $4.81 \mathrm{~b}$ & $10.34 \mathrm{~b}$ & $13.17 \mathrm{~b}$ & $14.70 \mathrm{~b}$ \\
\hline \multirow[t]{5}{*}{2020} & M & $12.67 \mathrm{a}$ & $33.50 \mathrm{a}$ & $149.00 \mathrm{ab}$ & $170.92 \mathrm{ab}$ & $5.15 \mathrm{a}$ & $11.57 \mathrm{a}$ & $13.82 \mathrm{ab}$ & $15.17 b$ \\
\hline & $\mathrm{T} 1$ & $12.67 \mathrm{a}$ & $37.33 \mathrm{a}$ & $160.33 \mathrm{a}$ & $178.35 \mathrm{a}$ & $5.55 \mathrm{a}$ & $12.38 \mathrm{a}$ & $14.68 \mathrm{a}$ & $16.10 \mathrm{a}$ \\
\hline & $\mathrm{T} 2$ & $13.67 \mathrm{a}$ & $35.00 \mathrm{a}$ & $153.33 \mathrm{ab}$ & $177.65 \mathrm{a}$ & $5.29 \mathrm{a}$ & $11.27 \mathrm{ab}$ & $13.70 \mathrm{ab}$ & $15.48 \mathrm{ab}$ \\
\hline & $\mathrm{T} 3$ & $13.33 \mathrm{a}$ & $34.50 \mathrm{a}$ & $151.00 \mathrm{ab}$ & $174.54 \mathrm{a}$ & $5.43 \mathrm{a}$ & $11.49 \mathrm{a}$ & $13.71 \mathrm{ab}$ & $15.51 \mathrm{ab}$ \\
\hline & Mean & $13.00 \mathrm{~A}$ & $33.07 \mathrm{~A}$ & 151.20 B & $173.46 \mathrm{~A}$ & $5.25 \mathrm{~A}$ & $11.41 \mathrm{~A}$ & $13.82 \mathrm{~A}$ & $15.39 \mathrm{~A}$ \\
\hline ANO & $\mathrm{Y}$ & $* *$ & ns & $* *$ & ns & $\mathrm{ns}$ & ns & ns & $* *$ \\
\hline \multirow[t]{2}{*}{ VA } & $\mathrm{T}$ & ns & $* *$ & $* *$ & $* *$ & * & $* *$ & * & $* *$ \\
\hline & $\mathrm{T} \times \mathrm{Y}$ & ns & * & * & $*$ & ns & ns & ns & $* *$ \\
\hline
\end{tabular}

Note: Lowercase and uppercase letters after each column of numbers indicate a significant difference at level 0.05 according to the LSD test comparison among each treatment in one year and all treatments between two growing seasons, respectively. T $\times \mathrm{Y}$, treatment $\times$ year. ns denotes non-significance at the 0.05 level. ${ }^{*} p<0.05 .{ }^{* *} p<0.01$.

Table 5. Effects of four treatments on the number of total leaves and green leaves of rapeseed.

\begin{tabular}{|c|c|c|c|c|c|c|c|c|c|}
\hline \multirow[b]{2}{*}{ Year } & \multirow[b]{2}{*}{ Treatment } & \multicolumn{4}{|c|}{ Number of Total Leaves } & \multicolumn{4}{|c|}{ Number of Green Leaves } \\
\hline & & $\begin{array}{l}\text { Seedling } \\
\text { Stage }\end{array}$ & $\begin{array}{c}\text { Bolting } \\
\text { Stage }\end{array}$ & $\begin{array}{l}\text { Flowering } \\
\text { Stage }\end{array}$ & $\begin{array}{l}\text { Pod } \\
\text { Stage }\end{array}$ & $\begin{array}{l}\text { Seedling } \\
\text { Stage }\end{array}$ & $\begin{array}{c}\text { Bolting } \\
\text { Stage }\end{array}$ & $\begin{array}{l}\text { Flowering } \\
\text { Stage }\end{array}$ & $\begin{array}{c}\text { Pod } \\
\text { Stage }\end{array}$ \\
\hline \multirow{3}{*}{ 2018-2019 } & CK & $8.44 \mathrm{a}$ & $15.11 \mathrm{~b}$ & $22.89 \mathrm{~b}$ & $24.11 \mathrm{~b}$ & $4.89 \mathrm{~b}$ & $8.00 \mathrm{c}$ & $13.22 \mathrm{a}$ & $1.78 \mathrm{~b}$ \\
\hline & $\mathrm{M}$ & $8.56 \mathrm{a}$ & $15.22 \mathrm{~b}$ & $24.67 \mathrm{ab}$ & $25.22 \mathrm{ab}$ & $5.22 \mathrm{~b}$ & $8.17 \mathrm{bc}$ & $13.56 \mathrm{a}$ & $5.33 \mathrm{a}$ \\
\hline & T1 & $9.00 \mathrm{a}$ & $15.89 \mathrm{ab}$ & $24.56 \mathrm{ab}$ & 25.67 a & $5.56 \mathrm{ab}$ & $10.00 \mathrm{a}$ & $13.33 \mathrm{a}$ & $2.94 \mathrm{ab}$ \\
\hline \multirow{8}{*}{ 2019-2020 } & $\mathrm{T} 2$ & $8.89 \mathrm{a}$ & 16.33 a & $25.67 \mathrm{a}$ & $25.56 \mathrm{a}$ & $5.78 \mathrm{ab}$ & $9.33 \mathrm{ab}$ & $14.89 \mathrm{a}$ & $4.11 \mathrm{ab}$ \\
\hline & $\mathrm{T} 3$ & $9.44 \mathrm{a}$ & $15.5 \mathrm{ab}$ & $24.56 \mathrm{ab}$ & $26.44 \mathrm{a}$ & $6.33 \mathrm{a}$ & $8.67 \mathrm{~b}$ & $13.33 \mathrm{a}$ & $4.78 \mathrm{a}$ \\
\hline & Mean & $8.87 \mathrm{~A}$ & $15.61 \mathrm{~A}$ & $24.47 \mathrm{~A}$ & $25.4 \mathrm{~A}$ & $5.56 \mathrm{~B}$ & $8.83 \mathrm{~B}$ & $13.67 \mathrm{~B}$ & $3.79 \mathrm{~A}$ \\
\hline & CK & $9.00 \mathrm{a}$ & $14.94 \mathrm{~b}$ & $22.00 \mathrm{c}$ & $24.88 \mathrm{~b}$ & $6.30 \mathrm{a}$ & $10.00 \mathrm{c}$ & $13.33 \mathrm{~b}$ & $2.35 \mathrm{~b}$ \\
\hline & M & $9.00 \mathrm{a}$ & $16.26 \mathrm{a}$ & $23.67 \mathrm{~b}$ & $25.63 \mathrm{a}$ & $6.30 \mathrm{a}$ & $11.00 \mathrm{~b}$ & $14.33 \mathrm{ab}$ & $4.87 \mathrm{a}$ \\
\hline & $\mathrm{T} 1$ & $9.33 \mathrm{a}$ & $16.26 \mathrm{a}$ & $24.00 \mathrm{ab}$ & $26.34 \mathrm{a}$ & $6.53 \mathrm{a}$ & $13.00 \mathrm{a}$ & $15.33 \mathrm{a}$ & $3.14 \mathrm{~b}$ \\
\hline & $\mathrm{T} 2$ & $9.00 \mathrm{a}$ & $16.00 \mathrm{a}$ & $25.00 \mathrm{a}$ & $26.28 \mathrm{a}$ & $6.30 \mathrm{a}$ & $13.67 \mathrm{a}$ & $15.33 \mathrm{a}$ & $3.88 \mathrm{ab}$ \\
\hline & T3 & $9.00 \mathrm{a}$ & $16.00 \mathrm{a}$ & $23.67 \mathrm{~b}$ & $25.91 \mathrm{a}$ & $6.30 \mathrm{a}$ & $11.67 \mathrm{~b}$ & $15.00 \mathrm{a}$ & $2.79 \mathrm{~b}$ \\
\hline & Mean & $9.07 \mathrm{~A}$ & $15.89 \mathrm{~A}$ & $23.67 \mathrm{~A}$ & $25.81 \mathrm{~A}$ & $6.35 \mathrm{~A}$ & $11.87 \mathrm{~A}$ & $14.66 \mathrm{~A}$ & $3.41 \mathrm{~A}$ \\
\hline ANO & $\mathrm{Y}$ & ns & ns & ns & ns & $* *$ & $* *$ & * & ns \\
\hline \multirow[t]{2}{*}{ VA } & $\mathrm{T}$ & ns & $* *$ & $* *$ & * & ns & $* *$ & * & $* *$ \\
\hline & $\mathrm{T} \times \mathrm{Y}$ & ns & ns & ns & ns & ns & $* *$ & ns & * \\
\hline
\end{tabular}

Note: Lowercase and uppercase letters after each column of numbers indicate a significant difference at level 0.05 according to the LSD test comparison among each treatment in one year and all treatments between two growing seasons, respectively. T $\times \mathrm{Y}$, treatment $\times$ year. ns denotes non-significance at the 0.05 level. ${ }^{*} p<0.05 .{ }^{* *} p<0.01$.

3.4. Effect of Wood Vinegar and Its Compounds with Three Regulating Substances on the Biomass and Leaf Area of Rapeseed

Wood vinegar and its compounds significantly increased the dry weight and fresh weight of rapeseed in each period, and the trend was the same (Table 6). The accumulation of dry matter increased rapidly at the bud bolting stage and decreased at the pod stage. Compared to the CK at the seedling, bud bolting, flowering, and pod stages, the biomass of rapeseed treated with $\mathrm{M}$ increased by an average of $39.56 \%, 46.45 \%, 23.09 \%$, and $14.02 \%$ in two years, respectively. The results showed that the growth increased the most effective during the seedling stage, and the treatments gradually became less effective as the growth period extended. The biomass of rapeseed treated with compound T1, T2, and T3 was 
higher than $\mathrm{M}$ in each period. The compound $\mathrm{T} 1$ increased biomass by an average of $11.13 \%, 23.43 \%, 23.30 \%$, and $10.41 \%$ in two years at the seedling, bud bolting, flowering, and pod stages, respectively. The compounds were most effective at the bud bolting and flowering stages of rapeseed.

Table 6. Effects of four treatments on the dry weight and fresh weight of rapeseed.

\begin{tabular}{|c|c|c|c|c|c|c|c|c|c|}
\hline \multirow[b]{2}{*}{ Year } & \multirow[b]{2}{*}{ Treatment } & \multicolumn{4}{|c|}{ Dry Weight (g) } & \multicolumn{4}{|c|}{ Fresh Weight (g) } \\
\hline & & $\begin{array}{l}\text { Seedling } \\
\text { Stage }\end{array}$ & $\begin{array}{l}\text { Bolting } \\
\text { Stage }\end{array}$ & $\begin{array}{c}\text { Flowering } \\
\text { Stage }\end{array}$ & $\begin{array}{c}\text { Pod } \\
\text { Stage }\end{array}$ & $\begin{array}{l}\text { Seedling } \\
\text { Stage }\end{array}$ & $\begin{array}{l}\text { Bolting } \\
\text { Stage }\end{array}$ & $\begin{array}{c}\text { Flowering } \\
\text { Stage }\end{array}$ & $\begin{array}{c}\text { Pod } \\
\text { Stage }\end{array}$ \\
\hline \multirow{4}{*}{ 2018-2019 } & CK & $1.56 \mathrm{~b}$ & $6.46 \mathrm{~b}$ & $15.22 \mathrm{c}$ & $30.83 \mathrm{~b}$ & $12.09 \mathrm{c}$ & $56.75 \mathrm{~b}$ & $111.67 \mathrm{c}$ & $141.11 \mathrm{c}$ \\
\hline & $\mathrm{M}$ & $2.48 \mathrm{a}$ & $9.56 \mathrm{ab}$ & $21.48 \mathrm{~b}$ & $35.70 \mathrm{ab}$ & $19.88 \mathrm{~b}$ & $95.60 \mathrm{a}$ & $168.33 \mathrm{~b}$ & $178.33 \mathrm{~b}$ \\
\hline & $\mathrm{T} 1$ & $2.66 \mathrm{a}$ & $12.75 \mathrm{a}$ & $29.88 \mathrm{a}$ & $40.65 \mathrm{a}$ & $24.61 \mathrm{ab}$ & $120.64 \mathrm{a}$ & $220.00 \mathrm{a}$ & $226.67 \mathrm{a}$ \\
\hline & $\mathrm{T} 2$ & $2.69 \mathrm{a}$ & $11.80 \mathrm{a}$ & $24.3 \mathrm{ab}$ & $36.20 \mathrm{ab}$ & $21.37 \mathrm{ab}$ & $117.88 \mathrm{a}$ & $182.22 \mathrm{ab}$ & $211.67 \mathrm{a}$ \\
\hline \multirow{7}{*}{ 2019-2020 } & T3 & $2.66 \mathrm{a}$ & $10.41 \mathrm{ab}$ & $23.05 \mathrm{ab}$ & $35.99 \mathrm{ab}$ & $25.77 \mathrm{a}$ & $106.60 \mathrm{a}$ & $177.78 \mathrm{ab}$ & $191.67 \mathrm{ab}$ \\
\hline & Mean & $2.41 \mathrm{~A}$ & 10.20 B & $22.79 \mathrm{~B}$ & $35.87 \mathrm{~A}$ & $20.74 \mathrm{~A}$ & $99.49 \mathrm{~B}$ & $172.00 \mathrm{~B}$ & $189.89 \mathrm{~A}$ \\
\hline & CK & $1.44 \mathrm{~b}$ & $9.62 b$ & $23.17 b$ & $31.98 \mathrm{~b}$ & $11.35 \mathrm{~b}$ & $86.75 b$ & $160.54 b$ & $173.69 \mathrm{~b}$ \\
\hline & $\mathrm{M}$ & $1.73 \mathrm{ab}$ & $13.94 \mathrm{a}$ & $24.34 \mathrm{ab}$ & $35.89 \mathrm{a}$ & $15.15 \mathrm{a}$ & $126.03 \mathrm{ab}$ & $177.84 \mathrm{ab}$ & $195.84 \mathrm{ab}$ \\
\hline & $\mathrm{T} 1$ & $1.99 \mathrm{a}$ & $15.82 \mathrm{a}$ & $26.16 \mathrm{a}$ & $38.38 \mathrm{a}$ & $16.85 \mathrm{a}$ & $145.75 \mathrm{a}$ & $197.29 \mathrm{a}$ & $213.73 \mathrm{a}$ \\
\hline & $\mathrm{T} 2$ & $1.74 \mathrm{ab}$ & $14.06 \mathrm{a}$ & $25.91 \mathrm{a}$ & $37.78 \mathrm{a}$ & $16.37 \mathrm{a}$ & $126.75 \mathrm{ab}$ & $194.35 \mathrm{a}$ & $201.29 \mathrm{a}$ \\
\hline & T3 & $1.87 \mathrm{a}$ & $14.14 \mathrm{a}$ & $25.71 \mathrm{a}$ & $37.77 \mathrm{a}$ & $16.70 \mathrm{a}$ & $125.00 \mathrm{ab}$ & $190.52 \mathrm{a}$ & $204.61 \mathrm{a}$ \\
\hline & Mean & $1.75 \mathrm{~B}$ & $13.52 \mathrm{~A}$ & $25.06 \mathrm{~A}$ & $36.36 \mathrm{~A}$ & $15.28 \mathrm{~B}$ & $122.06 \mathrm{~A}$ & $184.11 \mathrm{~A}$ & $197.83 \mathrm{~A}$ \\
\hline ANO & $\mathrm{Y}$ & $* *$ & $* *$ & * & ns & $* *$ & $* *$ & * & ns \\
\hline \multirow[t]{2}{*}{ VA } & $\mathrm{T}$ & $* *$ & $* *$ & $* *$ & $* *$ & $* *$ & $* *$ & $* *$ & $* *$ \\
\hline & $\mathrm{T} \times \mathrm{Y}$ & $*$ & $*$ & * & ns & $* *$ & $* *$ & ns & $*$ \\
\hline
\end{tabular}

Note: Lowercase and uppercase letters after each column of numbers indicate a significant difference at level 0.05 according to the LSD test comparison among each treatment in one year and all treatments between two growing seasons, respectively. T $\times \mathrm{Y}$, treatment $\times$ year. ns denotes non-significance at the 0.05 level. ${ }^{*} p<0.05$. ${ }^{* *} p<0.01$.

The four treatments could increase the area index of rapeseed at each growth stage (Table 7). The leaf area index (LAI) of the M treatment increased by an average of $17.86 \%$, $29.84 \%$, and $19.04 \%$ in two years compared to the CK at the seedling, bud bolting, and flowering stage, respectively. The pod area index (PAI) of the $\mathrm{M}$ treatment increased by an average of $27.04 \%$ in two years compared to the CK at the pod stage. The leaf area index of rapeseed treated with T1, T2, and T3 was higher than M at the seedling, bud bolting, and flowering stages. Especially, in the pod stage, the number of green leaves, leaf area, and SPAD value of $M$ treatment is still high, which indicates that $M$ has a strong effect on maintaining leaf function at the maturity stage and slowing down senescence. When $\mathrm{M}$ is mixed with different substances, it still has some effects in maintaining the function of leaves at the later stage of growth. Compared with different combinations, when $\mathrm{M}$ is mixed with gibberellin, the effect is reduced. The number of green leaves and leaf area index is significantly reduced, but they are still higher than the CK. On the whole, after mixing wood vinegar, the gibberellin can promote vegetative growth in the early and mid-term and accelerate the growth process, and it also has some effects on delaying the senescence of the leaves.

SPAD values had little difference during the seedling, bud bolting, and flowering stages among treatments. However, during the pod stage, the SPAD values were significantly higher than those in the $\mathrm{CK}$, which provided additional evidence that wood vinegar and its compounds could delay plant senescence.

\subsection{Response of Photosynthetic Rates of Rapeseed to Wood Vinegar and Its Compounds with Three Regulating Substances}

Photosynthesis $(A)$ and stomatal conductance $\left(g_{s}\right)$ were measured at different periods of rapeseed to observe the effects of different treatments on rapeseed physiological processes. The application of wood vinegar and its compounds with three regulating substances increased the net photosynthetic rate. Table 8 shows that the net photosynthetic rate of the four treatments was higher than that of the $\mathrm{CK}$ at the seedling and flowering 
stages. The net photosynthetic rates of the $\mathrm{M}, \mathrm{T} 1, \mathrm{~T} 2$, and $\mathrm{T} 3$ treatments at the seedling stage were an average of $9.40 \%, 26.96 \%, 19.07 \%$, and $14.92 \%$ in two years higher than that of the CK, respectively. The net photosynthetic rates of the M, T1, T2, and T3 treatments at the flowering stages increased by an average of $12.81 \%, 21.29 \%, 19.07 \%$, and $22.32 \%$ in two years compared to the $\mathrm{CK}$, respectively.

Table 7. Effects of four treatments on the leaf area index (LAI) and SPAD of rapeseed.

\begin{tabular}{|c|c|c|c|c|c|c|c|c|c|}
\hline \multirow[b]{2}{*}{ Year } & \multirow[b]{2}{*}{ Treatment } & \multicolumn{3}{|l|}{ LAI } & PAI & \multicolumn{2}{|l|}{ SPAD } & \multirow[b]{2}{*}{$\begin{array}{c}\text { Flowering } \\
\text { Stage }\end{array}$} & \multirow[b]{2}{*}{$\begin{array}{l}\text { Pod } \\
\text { Stage }\end{array}$} \\
\hline & & $\begin{array}{l}\text { Seedling } \\
\text { Stage }\end{array}$ & $\begin{array}{c}\text { Bolting } \\
\text { Stage }\end{array}$ & $\begin{array}{c}\text { Flowering } \\
\text { Stage }\end{array}$ & $\begin{array}{l}\text { Pod } \\
\text { Stage }\end{array}$ & $\begin{array}{c}\text { Seedling } \\
\text { Stage }\end{array}$ & $\begin{array}{l}\text { Bolting } \\
\text { Stage }\end{array}$ & & \\
\hline 2018- & CK & $2.31 \mathrm{c}$ & $3.59 \mathrm{~b}$ & $3.94 \mathrm{~b}$ & $3.34 \mathrm{~b}$ & $44.85 \mathrm{a}$ & $51.40 \mathrm{a}$ & $52.01 \mathrm{a}$ & $35.90 \mathrm{~b}$ \\
\hline \multirow[t]{5}{*}{2019} & $\mathrm{M}$ & $3.02 \mathrm{~b}$ & $4.32 \mathrm{a}$ & $4.63 \mathrm{a}$ & $4.04 \mathrm{a}$ & $44.83 \mathrm{a}$ & $52.04 \mathrm{a}$ & $53.42 \mathrm{a}$ & $42.83 \mathrm{a}$ \\
\hline & $\mathrm{T} 1$ & $3.57 \mathrm{a}$ & $4.79 \mathrm{a}$ & $4.81 \mathrm{a}$ & $3.56 \mathrm{~b}$ & $44.50 \mathrm{a}$ & $51.43 \mathrm{a}$ & $54.26 \mathrm{a}$ & $42.67 \mathrm{a}$ \\
\hline & $\mathrm{T} 2$ & $3.31 \mathrm{ab}$ & $4.67 \mathrm{a}$ & $4.75 \mathrm{a}$ & $3.94 \mathrm{a}$ & $44.90 \mathrm{a}$ & $53.13 \mathrm{a}$ & $52.19 \mathrm{a}$ & $42.53 \mathrm{a}$ \\
\hline & T3 & $3.34 \mathrm{ab}$ & $4.60 \mathrm{a}$ & $4.72 \mathrm{a}$ & $3.58 \mathrm{~b}$ & $44.93 \mathrm{a}$ & $51.82 \mathrm{a}$ & $52.68 \mathrm{a}$ & $41.37 \mathrm{a}$ \\
\hline & Mean & $3.11 \mathrm{~A}$ & $4.39 \mathrm{~A}$ & $4.57 \mathrm{~A}$ & $3.69 \mathrm{~A}$ & $44.80 \mathrm{~A}$ & $51.96 \mathrm{~A}$ & $52.91 \mathrm{~A}$ & $41.06 \mathrm{~B}$ \\
\hline 2019- & CK & $2.41 \mathrm{c}$ & $3.05 \mathrm{~b}$ & $3.50 \mathrm{~b}$ & $3.08 \mathrm{~b}$ & $42.57 \mathrm{a}$ & $51.73 \mathrm{a}$ & $52.05 \mathrm{a}$ & $40.31 \mathrm{~b}$ \\
\hline \multirow[t]{5}{*}{2020} & $\mathrm{M}$ & $2.53 \mathrm{bc}$ & $4.25 \mathrm{a}$ & $4.22 \mathrm{a}$ & $4.10 \mathrm{a}$ & $43.47 \mathrm{a}$ & $52.73 \mathrm{a}$ & $54.86 \mathrm{a}$ & $45.24 \mathrm{a}$ \\
\hline & $\mathrm{T} 1$ & $3.21 \mathrm{a}$ & $4.70 \mathrm{a}$ & $4.86 \mathrm{a}$ & $3.47 \mathrm{~b}$ & $43.23 \mathrm{a}$ & $54.97 \mathrm{a}$ & $53.39 \mathrm{a}$ & $44.81 \mathrm{a}$ \\
\hline & $\mathrm{T} 2$ & $2.95 \mathrm{~b}$ & $4.40 \mathrm{a}$ & $4.53 \mathrm{a}$ & $3.31 \mathrm{~b}$ & $41.60 \mathrm{a}$ & $54.30 \mathrm{a}$ & $52.41 \mathrm{a}$ & $44.13 \mathrm{a}$ \\
\hline & T3 & $3.01 \mathrm{ab}$ & $4.70 \mathrm{a}$ & $4.75 \mathrm{a}$ & $3.54 \mathrm{ab}$ & $42.50 \mathrm{a}$ & $53.83 \mathrm{a}$ & $53.94 \mathrm{a}$ & $43.29 \mathrm{a}$ \\
\hline & Mean & $2.82 \mathrm{~B}$ & $4.22 \mathrm{~A}$ & $4.37 \mathrm{~A}$ & $3.50 \mathrm{~A}$ & $42.67 \mathrm{~B}$ & $53.51 \mathrm{~A}$ & $53.33 \mathrm{~A}$ & $43.56 \mathrm{~A}$ \\
\hline ANO & $\mathrm{Y}$ & * & ns & ns & ns & $* *$ & ns & ns & $* *$ \\
\hline \multirow[t]{2}{*}{ VA } & $\mathrm{T}$ & $* *$ & $* *$ & $*$ & $* *$ & ns & ns & ns & $* *$ \\
\hline & $\mathrm{T} \times \mathrm{Y}$ & * & ns & ns & ns & ns & ns & ns & * \\
\hline
\end{tabular}

Note: Lowercase and uppercase letters after each column of numbers indicate a significant difference at level 0.05 according to the LSD test comparison among each treatment in one year and all treatments between two growing seasons, respectively. T $\times \mathrm{Y}$, treatment $\times$ year. ns denotes non-significance at the 0.05 level. ${ }^{*} p<0.05 .{ }^{* *} p<0.01$.

Table 8. Effects of the four treatments on photosynthesis and stomatal conductance of rapeseed.

\begin{tabular}{|c|c|c|c|c|c|c|c|}
\hline \multirow[b]{2}{*}{ Year } & \multirow[b]{2}{*}{ Treatment } & \multicolumn{3}{|c|}{$A\left(\mu \mathrm{mol} \mathrm{m}{ }^{-2} \mathrm{~s}^{-1}\right)$} & \multicolumn{3}{|c|}{$g_{s}\left(\mu \mathrm{mol} \mathrm{m}{ }^{-2} \mathrm{~s}^{-1}\right)$} \\
\hline & & $\begin{array}{l}\text { Seedling } \\
\text { Stage }\end{array}$ & $\begin{array}{c}\text { Bolting } \\
\text { Stage }\end{array}$ & $\begin{array}{l}\text { Flowering } \\
\text { Stage }\end{array}$ & $\begin{array}{l}\text { Seedling } \\
\text { Stage }\end{array}$ & $\begin{array}{l}\text { Bolting } \\
\text { Stage }\end{array}$ & $\begin{array}{c}\text { Flowering } \\
\text { Stage }\end{array}$ \\
\hline \multirow[t]{6}{*}{$2018-2019$} & CK & $14.80 \mathrm{~b}$ & $24.73 \mathrm{a}$ & $16.74 \mathrm{~b}$ & $0.13 \mathrm{a}$ & $0.30 \mathrm{a}$ & $0.25 \mathrm{a}$ \\
\hline & M & $16.21 \mathrm{ab}$ & $25.36 \mathrm{a}$ & $19.45 \mathrm{ab}$ & $0.13 \mathrm{a}$ & $0.35 \mathrm{a}$ & $0.28 \mathrm{a}$ \\
\hline & $\mathrm{T} 1$ & $18.00 \mathrm{a}$ & $25.59 \mathrm{a}$ & $20.05 \mathrm{ab}$ & $0.15 \mathrm{a}$ & $0.38 \mathrm{a}$ & $0.39 \mathrm{a}$ \\
\hline & $\mathrm{T} 2$ & $16.49 \mathrm{ab}$ & $24.75 \mathrm{a}$ & $20.59 \mathrm{ab}$ & $0.13 \mathrm{a}$ & $0.38 \mathrm{a}$ & $0.39 \mathrm{a}$ \\
\hline & T3 & $16.98 \mathrm{ab}$ & $24.10 \mathrm{a}$ & $22.49 \mathrm{a}$ & $0.14 \mathrm{a}$ & $0.36 \mathrm{a}$ & $0.34 \mathrm{a}$ \\
\hline & Mean & $16.50 \mathrm{~B}$ & $24.91 \mathrm{~A}$ & $19.86 \mathrm{~A}$ & $0.14 \mathrm{~B}$ & $0.35 \mathrm{~B}$ & $0.33 \mathrm{~A}$ \\
\hline \multirow[t]{6}{*}{ 2019-2020 } & CK & $14.89 \mathrm{~b}$ & $22.65 \mathrm{c}$ & $16.13 \mathrm{~b}$ & $0.14 \mathrm{~b}$ & $0.39 \mathrm{a}$ & $0.22 \mathrm{a}$ \\
\hline & M & $16.27 \mathrm{ab}$ & $23.63 \mathrm{bc}$ & $17.65 \mathrm{ab}$ & $0.17 \mathrm{ab}$ & $0.46 \mathrm{a}$ & $0.28 \mathrm{a}$ \\
\hline & $\mathrm{T} 1$ & $19.70 \mathrm{a}$ & $27.08 \mathrm{a}$ & $19.81 \mathrm{a}$ & $0.20 \mathrm{a}$ & $0.47 \mathrm{a}$ & $0.35 \mathrm{a}$ \\
\hline & $\mathrm{T} 2$ & $18.87 \mathrm{a}$ & $25.95 \mathrm{ab}$ & $18.57 \mathrm{ab}$ & $0.17 \mathrm{ab}$ & $0.46 \mathrm{a}$ & $0.34 \mathrm{a}$ \\
\hline & T3 & $17.14 \mathrm{ab}$ & $24.18 \mathrm{~b}$ & $17.79 \mathrm{ab}$ & $0.18 \mathrm{ab}$ & $0.43 \mathrm{a}$ & $0.30 \mathrm{a}$ \\
\hline & Mean & $17.37 \mathrm{~A}$ & $24.70 \mathrm{~A}$ & $17.99 \mathrm{~B}$ & $0.17 \mathrm{~A}$ & $0.44 \mathrm{~A}$ & $0.30 \mathrm{~A}$ \\
\hline ANO & Y & $* *$ & ns & $* *$ & $* *$ & $* *$ & ns \\
\hline \multirow{2}{*}{ VA } & $\mathrm{T}$ & $* *$ & * & $* *$ & ns & ns & ns \\
\hline & $\mathrm{T} \times \mathrm{Y}$ & * & ns & $*$ & ns & ns & ns \\
\hline
\end{tabular}

Note: Lowercase and uppercase letters after each column of numbers indicate a significant difference at level 0.05 according to the LSD test comparison among each treatment in one year and all treatments between two growing seasons, respectively. T $\times Y$, treatment $\times$ year. ns denotes non-significance at the 0.05 level. ${ }^{*} p<0.05 .{ }^{* *} p<0.01$. A, photosynthesis. $g$ s, stomatal conductance.

There was no significant difference in the effect of wood vinegar and compound on stomatal conductance (Table 8). However, the stomatal conductance of the four treatments at varying growth stages was higher than that of the $\mathrm{CK}$, particularly at the bud bolting and flowering stages. Among them, T1 was the highest during all three growth stages. 
These results indicate that the use of wood vinegar and its compounds increased the net photosynthetic rate and expanded the stomatal conductance of rapeseed.

3.6. Wood Vinegar and Its Compounds with Three Regulating Substances Improved the Stress Resistance of Rapeseed at Low Temperature

The sampling analysis of plants exposed to a low temperature of $2-6^{\circ} \mathrm{C}$ during the bud bolting stage revealed that different treatments could improve the resistance of rapeseed to low temperatures (Table 9). The content of soluble protein, chlorophyll content, proline, and superoxide dismutase of wood vinegar and the compound treatment were higher than those of the CK. The contents of chlorophyll and proline in the M treatment increased by an average of $29.10 \%$ and $103.98 \%$ in two years, respectively, and the content of superoxide dismutase increased significantly by $20.93 \%$ in two years compared to the CK. Alternatively, the content of malondialdehyde in wood vinegar and the compound tended to decrease, indicating that the application of wood vinegar could effectively scavenge the free radicals produced in the rapeseed under low-temperature stress, reduce the damage caused by low temperature, and enhance its resistance to stress at low temperatures. The combination of wood vinegar with gibberellin, sodium gluconate, and melatonin dramatically improved the resistance of the rapeseed to stress.

Table 9. Effects of the four treatments on physiological indices of rapeseed at low temperature.

\begin{tabular}{|c|c|c|c|c|c|c|c|c|}
\hline Year & Treatment & $\begin{array}{l}\text { Soluble Protein } \\
\text { (mg/g) }\end{array}$ & $\begin{array}{c}\text { Chlorophyll } \\
\text { Content } \\
\text { (mg/g) }\end{array}$ & $\begin{array}{c}\text { MDA } \\
\text { (umol/g) }\end{array}$ & $\begin{array}{l}\text { Proline } \\
\text { (ug/g) }\end{array}$ & $\begin{array}{c}\text { SOD } \\
\text { (U/mg prot) }\end{array}$ & $\begin{array}{c}\text { POD } \\
\text { (U/mg prot) }\end{array}$ & $\begin{array}{c}\text { CAT } \\
\text { (U/mg prot) }\end{array}$ \\
\hline \multirow[t]{5}{*}{ 2018-2019 } & CK & $56.55 \mathrm{~b}$ & $1.30 \mathrm{c}$ & $4.99 \mathrm{a}$ & $176.56 \mathrm{c}$ & $0.86 \mathrm{~b}$ & $1.55 \mathrm{a}$ & $4.54 \mathrm{a}$ \\
\hline & $\mathrm{M}$ & $65.34 \mathrm{ab}$ & $1.54 \mathrm{a}$ & $4.85 \mathrm{a}$ & $472.16 \mathrm{a}$ & $1.04 \mathrm{a}$ & $1.37 \mathrm{a}$ & $3.89 \mathrm{~b}$ \\
\hline & T1 & $67.35 \mathrm{a}$ & $1.42 \mathrm{~b}$ & $4.76 \mathrm{a}$ & $345.74 \mathrm{~b}$ & $1.02 \mathrm{a}$ & $1.36 \mathrm{a}$ & $3.82 \mathrm{~b}$ \\
\hline & $\mathrm{T} 2$ & $64.36 \mathrm{ab}$ & $1.36 \mathrm{bc}$ & $4.54 \mathrm{a}$ & $297.60 \mathrm{~b}$ & $1.00 \mathrm{a}$ & $1.31 \mathrm{a}$ & $3.95 \mathrm{ab}$ \\
\hline & T3 & 68.37 a & $1.45 \mathrm{ab}$ & $4.81 \mathrm{a}$ & $255.44 \mathrm{bc}$ & $1.01 \mathrm{a}$ & $1.30 \mathrm{a}$ & $3.73 \mathrm{~b}$ \\
\hline \multirow{2}{*}{ 2019-2020 } & CK & $63.90 \mathrm{~b}$ & $1.46 \mathrm{~b}$ & $4.50 \mathrm{a}$ & $139.80 \mathrm{~b}$ & $1.05 \mathrm{~b}$ & $2.00 \mathrm{a}$ & $3.03 \mathrm{a}$ \\
\hline & M & $66.96 \mathrm{a}$ & $2.04 \mathrm{a}$ & $4.22 \mathrm{a}$ & $196.48 \mathrm{a}$ & $1.20 \mathrm{a}$ & $1.75 \mathrm{a}$ & $2.42 \mathrm{~b}$ \\
\hline
\end{tabular}

Note: MDA, malondialdehyde. SOD, superoxide dismutase. POD, peroxidase. CAT, catalase. Different lowercase letters after each column of numbers indicate $p<0.05$.

3.7. Wood Vinegar and Its Compounds with Three Regulating Substances Reduced the Incidence of Sclerotinia Sclerotiorum and Peronospora Parasitica

The four treatments reduced the incidence of Sclerotinia sclerotiorum and Peronospora parasitica in rapeseed (Table 10). The incidence of Sclerotinia sclerotiorum and Peronospora parasitica in rapeseed treated with $\mathrm{M}$ decreased, but the difference was not significant compared to the CK. The incidence of Sclerotinia sclerotiorum and Peronospora parasitica of rapeseed treated with $\mathrm{T} 1, \mathrm{~T} 2$, and $\mathrm{T} 3$ was significantly reduced compared to $\mathrm{M}$. The two diseases mentioned above in the T3 treatment decreased $22.60 \%$ and $11.33 \%$ compared to the CK, respectively.

Table 10. Effects of the four treatments on the incidence of Sclerotinia sclerotiorum and Peronospora parasitica in rapeseed.

\begin{tabular}{|c|c|c|c|c|c|}
\hline Year & Treatment & $\begin{array}{l}\text { Rate of Incidence } \\
\text { of Sclerotinia } \\
\text { sclerotiorum }(\%)\end{array}$ & $\begin{array}{l}\text { Rate of Reduction } \\
\text { of Sclerotinia } \\
\text { sclerotiorum (\%) }\end{array}$ & $\begin{array}{c}\text { Rate of Incidence } \\
\text { of Peronospora } \\
\text { parasitica }(\%)\end{array}$ & $\begin{array}{c}\text { Rate of Reduction } \\
\text { of Peronospora } \\
\text { parasitica }(\%)\end{array}$ \\
\hline \multirow[t]{5}{*}{ 2018-2019 } & CK & $57.33 \mathrm{a}$ & 0 & $40.00 \mathrm{a}$ & 0 \\
\hline & M & $50.67 \mathrm{ab}$ & 6.66 & $36.67 \mathrm{a}$ & 3.33 \\
\hline & $\mathrm{T} 1$ & $40.00 \mathrm{bc}$ & 17.33 & $36.00 \mathrm{ab}$ & 4.00 \\
\hline & $\mathrm{T} 2$ & $44.00 \mathrm{~b}$ & 13.33 & $35.33 \mathrm{ab}$ & 4.63 \\
\hline & T3 & $34.67 \mathrm{c}$ & 22.66 & $28.67 \mathrm{~b}$ & 11.33 \\
\hline \multirow[t]{2}{*}{ 2019-2020 } & CK & $45.00 \mathrm{a}$ & 0 & $33.33 \mathrm{a}$ & 0 \\
\hline & $\mathrm{M}$ & $40.50 \mathrm{a}$ & 4.50 & $27.50 \mathrm{a}$ & 5.83 \\
\hline
\end{tabular}

Note: Different lowercase letters after each column of numbers indicate $p<0.05$. 


\section{Discussion}

\subsection{The Main Components and Functions of Wood Vinegar}

The composition of wood vinegar is very complicated, but studies have shown that its main components are acids and phenols (Table 1), both of which have high biological activity and promote plant growth [18,34]. After the $\mathrm{H}^{+}$in the acid substance enters the leaf tissue, it can cause intercellular acidification, and enhance the cell activity, thereby increasing the vigor of the plant. A previous study in rice found that the primary substances of wood vinegar that promote seed germination and seedling growth are acids and their derivatives [35]. Further studies also confirmed that treatment with acetic acid can keep rice plants growing normally under drought conditions [36]. The phenolic substances in wood vinegar, especially dihydric phenols and polyphenols, can also significantly promote plant growth at low concentrations [37,38]. A study on tomatoes found that wood vinegar can stimulate the increase of auxin, gibberellin, and various enzyme activities and promote plant growth and nitrogen absorption. The author believes that this stimulating effect is mainly caused by phenolic substances of wood vinegar [39]. Studies have also shown that the butenolide in wood vinegar can stimulate seed germination and promote plant growth $[40,41]$. Furan and its derivatives in wood vinegar may be hormone-like substances that stimulate plant growth [42]. In summary, there are many substances in wood vinegar that are conducive to crop growth and improve stress resistance. Among them, acids (such as acetic acid and butyric acid) and phenol play a major role, as well as the combined effects of butenolide, furan, and its derivatives. Only at an appropriate concentration, all the substances that have a promoting effect in the wood vinegar will achieve a peaceful interaction state, coordinate the growth of crops from different aspects, and produce a positive effect that exceeds the application of a single plant hormone regulator.

\subsection{The Combined Effect of Wood Vinegar and Other Regulatory Substances}

A comparative study on the treatment with wood vinegar and its compounds showed that the interaction of gibberellin, sodium gluconate, and melatonin with wood vinegar produced a significant positive effect (Tables 2, 4 and 7). As mentioned earlier, the composition of wood vinegar is complex, containing acids, phenols, and other vitamin B substances that promote crop growth [43]. Using wood vinegar at an appropriate concentration enhanced root growth, stress resistance, and anti-aging mechanism [44,45]. Our results demonstrated that the combination of wood vinegar and gibberellin has the best effect on rapeseed yield among the three combinations. The possible reason is that gibberellin treatment can significantly promote crop internode elongation, increases plant height and leaf area, and enhance biomass significantly [46]. However, gibberellin has the problem of slender stalk growth of plants and rapid senescence in the late growth period. Therefore, the combined application of gibberellin and wood vinegar can significantly enhance the robust growth and root neck of plants based on maintaining the effect of gibberellin on promoting growth and flowering (Table 4 ) and improve the resistance to cold stress. The combined effect of wood vinegar and gibberellin can significantly increase the number of pods and increase the number and weight of seeds (Table 1). It can also enhance the leaf function in the later stage of growth, which results in good interaction advantages. The combination of sodium gluconate and wood vinegar further increased the yield since sodium gluconate can promote the robust growth of seedlings and raise the number of pods in the late growth period [11]. The combination of melatonin and wood vinegar has more obvious positive effects on rapeseed during the late growth period, and this feature may be related to an essential role of melatonin in delaying leaf senescence [47].

\subsection{Wood Vinegar Can Improve the Abiotic Stress Resistance of Rapeseed}

Wood vinegar treatment can improve the ability of crops to resist a low temperature, drought, and salt damage. This study indicated that spraying wood vinegar and its compounds on rapeseed can increase its cold resistance during the bud bolting stage at a low temperature of $2-6^{\circ} \mathrm{C}$ (Table 9), consistent with the results of previous studies [42]. Treat- 
ing seeds with wood vinegar also has the effect of improving crop resistance. Seed soaking in a wood vinegar solution can significantly increase the content of abscisic acid and the activity of antioxidant enzymes in the roots of wheat under drought conditions by reducing the content of malondialdehyde, and thus improve the drought resistance of wheat [26] and reduce the damage of salt stress to rice seedlings [48]. These studies have confirmed that wood vinegar can increase the antioxidant capacity by enhancing the activity of antioxidant enzymes such as superoxide dismutase and regulate the content of osmotic substances such as proline and soluble protein to reduce the osmotic potential of cells and reduce cold stress.

\subsection{Wood Vinegar Can Improve the Disease Resistance of Crops}

Wood vinegar has a broad spectrum of resistance to fungi. Studies have shown that wood vinegar can effectively inhibit Pythium, Penicillium, Rhizobium, Sclerotinia, and Fusarium [49]. This study confirmed that wood vinegar and its compounds could reduce the incidence of Sclerotinia sclerotiorum and Peronospora parasitica in rapeseed (Table 10). The results of different studies also demonstrated the more obvious antibacterial effects of wood vinegar on Phytophthora capsici, Fusarium solani, Verticillium dahliae, Cucumber anthracnose, and Tobacco mosaic $[50,51]$. The ability of wood vinegar to inhibit fungi is mainly achieved by inhibiting the division speed, destroying cell membranes, leaking electrolytes, and inhibiting protein synthesis $[18,52]$, and the inhibitory activity increases with the increase of wood vinegar concentration. The current study believes that the prominent antibacterial effect of wood vinegar is due to many phenolic substances [53]. Therefore, wood vinegar is being developed as a new type of antifungal agent, which uses its advantages of high purity, no pollution, and no residue meets the global scientific requirements for reducing chemical pesticides and has a broad application space. This study shows that the combined application of melatonin and wood vinegar can significantly improve the disease resistance of plants, which is worthy of further research.

\section{Conclusions}

The 400-fold dilution of wood vinegar significantly increased plant height, total leaf number, green leaf number, leaf area, effective branch number, and pod number per plant. In particular, it significantly increased the leaf area index and accumulation of rapeseed dry matter. The application of wood vinegar could delay the shedding and senescence of leaves in the pod stage, facilitating the accumulation of dry matter and transportation to fruiting organs during the later growth stage. Thus, it significantly increased the number of effective pods and seed yield of rapeseed. The application of wood vinegar can also improve the resistance of rapeseed to low temperatures and diseases. A suitable concentration of gibberellin, sodium gluconate, and melatonin interacts with wood vinegar to promote growth and increase yield. The mixture of diluted 400 -fold wood vinegar and $25 \mathrm{mg} \mathrm{L}^{-1}$ gibberellin was the most effective, and the yield was significantly higher than that of wood vinegar alone. The combination of melatonin and wood vinegar significantly improved the resistance of the plant to disease.

Author Contributions: L.H. conceived and designed the experiments; K.Z. (Kunmiao Zhu) and S.G. performed the experiments; K.Z. (Kangkang Zhang) helped in experiment; J.L. and T.L. analyzed the data; K.Z. (Kunmiao Zhu) wrote the paper; L.H. and Z.K. revised the manuscript. All authors have read and agreed to the published version of the manuscript.

Funding: This research and the APC was funded by Hubei Agricultural Science and Technology Innovation Project (07601903); Huazhong Agricultural University First-class Discipline Construction Project.

Acknowledgments: This work was supported by the Hubei Agricultural Science and Technology Innovation Project, Huazhong Agricultural University First-class Discipline Construction Project. We thank Yunbi $\mathrm{Xu}$ for his helpful comments and suggestions.

Conflicts of Interest: The authors declare no conflict of interest. 


\section{References}

1. Kuai, J.; Yang, Y.; Sun, Y.; Zhou, G.; Zuo, Q.; Wu, J.; Ling, X. Paclobutrazol increases canola seed yield by enhancing lodging and pod shatter resistance in Brassica napus L. Field Crops Res. 2015, 180, 10-20. [CrossRef]

2. Davies, P.J. (Ed.) The Plant Hormones: Their Nature, Occurrence, and Functions. In Plant Hormones; Springer: Dordrecht, The Netherlands, 2010; pp. 1-15.

3. Pan, S.; Rasul, F.; Li, W.; Tian, H.; Mo, Z.; Duan, M.; Tang, X. Roles of plant growth regulators on yield, grain qualities and antioxidant enzyme activities in super hybrid rice (Oryza sativa L.). Rice 2013, 6, 9. [CrossRef] [PubMed]

4. Aftab, T.; Khan, M.M.; Idrees, M.; Naeem, M.; Hashmi, N. Effects of gibberellic acid on growth, photosynthetic efficiency and artemisinin content of Artemisia annua L. Plant Sci. Biotechnol. 2010, 5, 25-29.

5. Idrees, M.; Aftab, T.; Naeem, M.; Hashmi, N. Salicylic acid-induced physiological and biochemical changes in lemongrass varieties under water stress. J. Plant Interact. 2010, 5, 293-303. [CrossRef]

6. Zheng, L.; Wu, W.; Yan, C.; Zhang, Y.; Xu, Y.; Xu, R.; Wang, H.; Cui, N.; Chen, Z. Effects of plant growth regulators on photosynthetic rate and yield components of rice. Crops 2011, 3, 63-66.

7. Arnao, M.B.; Hernández, J. Melatonin: Plant growth regulator and/or biostimulator during stress. Trends Plant Sci. 2014, 19, 789-797. [CrossRef]

8. Kariali, E.; Mohapatra, P.K. Hormonal regulation of tiller dynamics in differentially-tillering rice cultivars. Plant Growth Regul. 2007, 53, 215-223. [CrossRef]

9. Wei, W.; Li, Q.; Chu, Y.; Reiter, R.J.; Yu, X.; Zhu, D.; Zhang, W.; Ma, B.; Lin, Q.; Zhang, J. Melatonin enhances plant growth and abiotic stress tolerance in soybean plants. J. Exp. Bot. 2015, 66, 695-707. [CrossRef]

10. Li, P.; Chen, B.; Ding, F. Gluconate enhanced the water uptake and improved the growth of rice seedlings under PEG-induced osmotic stress. Plant Physiol. Biochem. 2020, 156, 514-523. [CrossRef]

11. Gourkhede, P.H.; Patil, V.D.; Pathrikar, D.T. Effect of foliar feeding of gluconate and EDTA chelated plant nutrients on yield, quality and nutrient concentration in Bt cotton. Cotton Res. Dev. Assoc. 2017, 31, 74-81.

12. Nasri, M.; Khalatbari, M.; Farahani, H.A. Zn-foliar application influence on quality and quantity features in Phaseolous vulgaris under different levels of $\mathrm{N}$ and $\mathrm{K}$ fertilizers. Adv. Environ. Biol. 2011, 5, 839-846.

13. Yu, L.; Lin, A.; Li, T.; Yuan, L.; Zhao, Q. Effects of spraying low molecular organic compounds on growth and nutrients uptake of rape (Brassica Chinensis L.). J. Plant Nutr. Fertil. 2014, 20, 1560-1568.

14. Tiilikkala, K.; Fagernäs, L.; Tiilikkala, J. History and use of wood pyrolysis liquids as biocide and plant protection product. Open Agric. 2010, 4, 111-118. [CrossRef]

15. Zhang, A.; Bian, R.; Pan, G.; Cui, L.; Hussain, Q.; Li, L.; Zheng, J.; Zheng, J.; Zhang, X.; Han, X.; et al. Effects of biochar amendment on soil quality, crop yield and greenhouse gas emission in a Chinese rice paddy: A field study of 2 consecutive rice growing cycles. Field Crops Res. 2012, 127, 153-160. [CrossRef]

16. Grewal, A.; Abbey Gunupuru, L.R. Production, prospects and potential application of pyroligneous acid in agriculture. J. Anal. Appl. Pyrolysis 2018, 135, 152-159. [CrossRef]

17. Bilehal, D.; Li, L.; Kim, Y.H. Gas Chromatography-Mass Spectrometry Analysis and Chemical Composition of the BambooCarbonized Liquid. Food Anal. Methods 2012, 5, 109-112. [CrossRef]

18. Qin, W.; Ma, X.; Zhao, Z.; Zhang, S.; Liu, S. Antioxidant activities and chemical profiles of pyroligneous acids from walnut shell. J. Anal. Appl. Pyrolysis 2010, 88, 149-154.

19. Ma, X.; Wei, Q.; Zhang, S.; Shi, L.; Zhao, Z. Isolation and bioactivities of organic acids and phenols from walnut shell pyroligneous acid. J. Anal. Appl. Pyrolysis 2011, 91, 338-343. [CrossRef]

20. Ma, C.; Song, K.; Yu, J.; Yang, L.; Zhao, C.; Wang, W.; Zu, G.; Zu, Y. Pyrolysis process and antioxidant activity of pyroligneous acid from Rosmarinus officinalis leaves. J. Anal. Appl. Pyrolysis 2013, 104, 38-47. [CrossRef]

21. Flematti, G.R.; Ghisalberti, E.L.; Dixon, K.W.; Trengove, R.D. A compound from smoke that promotes seed germination. Science 2004, 305, 977. [CrossRef]

22. Nelson, D.C.; Flematti, G.R.; Ghisalberti, E.L.; Dixon, K.W.; Smith, S.M. Regulation of seed germination and seedling growth by chemical signals from burning vegetation. Annu. Rev. Plant Biol. 2012, 63, 107-130. [CrossRef]

23. Chalermsan, Y.; Peerapan, S. Wood vinegar: By-product from rural charcoal kiln and its role in plant protection. Asian J. Food Ag-Ind. 2009, 2, 189-195.

24. Simma, B.; Polthanee, A.; Goggi, A.S. Wood vinegar seed priming improves yield and suppresses weeds in dryland direct-seeding rice under rainfed production. Agron. Sustain. Dev. 2017, 37, 56. [CrossRef]

25. Jeong, K.W.; Kim, B.S.; Ultra, V.U.; Lee, S.C. Effects of Rhizosphere Microorganisms and Wood Vinegar Mixtures on Rice Growth and Soil Properties. Korean J. Crop. Sci. 2015, 60, 355-365. [CrossRef]

26. Wang, Y.; Qiu, L.; Song, Q.; Wang, S.; Wang, Y.; Ge, Y. Root Proteomics Reveals the Effects of Wood Vinegar on Wheat Growth and Subsequent Tolerance to Drought Stress. Int. J. Mol. Sci. 2019, 20, 943. [CrossRef]

27. Gu, S.; Zhu, K.; Geng, M.; Jiang, X.; Xu, Z.; Hu, L. Leaf spray of wood vinegar and its effect on rapeseed seedling growth. Chin. J. Oil Crop Sci. 2020, 42, 453-460.

28. Bradford, M.M. A rapid and sensitive method for the quantitation of microgram quantities of protein utilizing the principle of protein-dye binding. Anal. Biochem. 1976, 72, 248-254. [CrossRef] 
29. Porra, R.J.; Thompson, W.A.; Kriedemann, P.E. Determination of accurate extinction coefficients and simultaneous equations for assaying chlorophylls a and b extracted with four different solvents: Verification of the concentration of chlorophyll standards by atomic absorption spectroscopy. Biochim. Biophys. Acta Bioenerg. 1989, 975, 384-394. [CrossRef]

30. Zhou, W.; Leul, M. Uniconazole-induced alleviation of freezing injury in relation to changes in hormonal balance, enzyme activities and lipid peroxidation in winter rape. Plant Growth Regul. 1998, 26, 41-47. [CrossRef]

31. Shan, D.; Huang, J.; Yang, Y.; Guo, Y.; Wu, C.; Yang, G.; Gao, Z.; Zheng, C. Cotton GhDREB1 increases plant tolerance to low temperature and is negatively regulated by gibberellic acid. New Phytol. 2007, 176, 70-81. [CrossRef]

32. Hwang, S.Y.; Lin, H.W.; Chern, R.H.; Lo, H.F.; Li, L. Reduced susceptibility to waterlogging together with high-light stress is related to increases in superoxide dismutase and catalase activities in sweet potato. Plant Growth Regul. 1999, 27, 167-172. [CrossRef]

33. Duan, Y.; Liu, S.; Ge, C.; Feng, X.; Chen, C.; Zhou, M. In vitro inhibition of Sclerotinia sclerotiorum by mixtures of azoxystrobin, sham, and thiram. Pestic. Biochem. Physiol. 2012, 103, 101-107. [CrossRef]

34. Mungkunkamchao, T.; Kesmala, T.; Pimratch, S.; Toomsan, B.; Jothityangkoon, D. Wood vinegar and fermented bioextracts: Natural products to enhance growth and yield of tomato (Solanum lycopersicum L.). Sci. Hortic. 2013, 154, 66-72. [CrossRef]

35. Shen, F.; Lu, J.; Tai, J. Study on the effect of wood vinegar on rice germination and growth. J. Agric. Sci. Yanbian Univ. 2002, 24, 26-29.

36. Kim, J.M.; To, T.K.; Matsui, A.; Tanoi, K.; Kobayashi, N.I.; Matsuda, F. Acetate-mediated novel survival strategy against drought in plants. Nat. Plants 2017, 3, 17097. [CrossRef]

37. Lin, K.; Ye, F.; Lin, Y.; Li, Q. Research progress on the mechanism of phenolic substances on soil and plants. J. Eco-Agric. 2010, 5, 1130-1137.

38. Yan, Y.; Lu, X.; Li, L.; Zheng, J.; Pan, G. The composition of straw pyrolysis wood vinegar and its effect on the growth and quality of pepper. J. Nanjing Agric. Univ. 2011, 5, 58-62.

39. Zhang, L.; Wang, L.; Liu, X.; Guo, D. The effect of wood vinegar as foliar fertilizer on tomato growth. Zhejiang Agric. Sci. 2019, 2, 231-233.

40. Zhou, J.; Teixeira da Silva, J.; Ma, G. Effects of smoke water and karrikin on seed germination of 13 species growing in China. Open Life Sci. 2014, 9, 1108-1116. [CrossRef]

41. Chiwocha, S.D.S.; Dixon, K.W.; Flematti, G.R.; Ghisalberti, E.L.; Merritt, D.J.; Nelson, D.C.; Riseborough, J.A.M.; Smith, S.M.; Stevens, J.C. Karrikins: A new family of plant growth regulators in smoke. Plant Sci. 2009, 177, 252-256. [CrossRef]

42. Zhai, M.; Shi, G.; Wang, Y.; Mao, G.; Wang, D.; Wang, Z. Chemical Compositions and Biological Activities of Pyroligneous Acids from Walnut Shell. Bioresources 2015, 10, 1715-1729. [CrossRef]

43. Mao, K.; Li, S.; Li, B.; Wu, W.; Yuan, S.; Niu, Y.; Du, H.; Zhang, L. Effects of wood vinegar on the growth, yield and quality of upper leaves of Nanzheng flue-cured tobacco. J. Southwest Agric. 2019, 3, 645-652.

44. Kulkarni, M.G.; Ascough, G.D.; Verschaeve, L.; Baeten, K.; Arruda, M.P.; Staden, J.V. Effect of smoke-water and a smoke-isolated butenolide on the growth and genotoxicity of commercial onion. Sci. Hortic. 2010, 124, 434-439. [CrossRef]

45. Cao, Y.; Zhang, H.; Meng, J.; Yang, Q.; Zhang, X.; Kang, Z.; Zhou, G. Effect of the combined action of wood vinegar and sodium naphthaleneacetate on photosynthetic characteristics and yield of peanuts. Agric. Res. Arid. Areas 2017, 1, 185-191.

46. Zheng, L.; Yuan, X.; Shao, D.; Tian, S.; Chen, J.; Shi, H.; Guo, P. The effect of spraying gibberellin during the filling stage on the agronomic characteristics and yield of millet. Shanxi Agric. Sci. 2014, 5, 455-457.

47. Ke, X.; Xu, P.; Yin, L.H.; Wang, Z.H.; Zhang, P.P.; Diao, J.J.; Zuo, Y.H.; Zheng, D.F. Exogenous application of melatonin delays leaf senescence in adzuki bean. J. Heilongjiang Bayi Agric. Univ. 2015, 27, 52-55.

48. Theerakulpisut, P.; Kanawapee, N.; Panwong, B. Seed priming alleviated salt stress effects on rice seedlings by improving $\mathrm{Na}^{+} / \mathrm{K}^{+}$ and maintaining membrane integrity. Int. J. Plant Biol. 2016, 7, 53-58. [CrossRef]

49. Quan, S. Application of wood vinegar to control diseases. J. Agric. Sci. Yanbian Univ. 1994, 2, $113-116$.

50. Mao, Q.; Ding, F.; Zhao, Z.; Ma, X. Preparation of apricot tree vinegar and its antibacterial activity and chemical composition analysis. J. Northwest A F Univ. 2009, 37, 91-96.

51. Zeng, J.; Hai, M.; Wang, X. The effect of Dabuxilatu wood vinegar on the quality and disease of organic tobacco. Agric. Sci. Bull. 2014, 7, 162-167.

52. Zhang, L.; Wang, L.D.; Gong, W. Chemical constituents and antibacterial activity of jujube kernel vinegar. Food Sci. 2016, 37, 123-127.

53. Wei, Q.; Ma, X.; Xu, M. Chemical composition analysis and antibacterial test of poplar vinegar. For. Sci. 2008, 44, 98-102. 